\title{
10. LATEST MIOCENE TO QUATERNARY BIOSTRATIGRAPHY AND PALEOCEANOGRAPHY, SITE 704, SUBANTARCTIC SOUTH ATLANTIC OCEAN1
}

\author{
Charlotte A. Brunner ${ }^{2}$
}

\begin{abstract}
The planktonic foraminiferal zonation of Jenkins and Srinivasan (1986), which was defined for the southwestern sector of the temperate South Pacific Ocean, was successfully extended to the temperate sequences at Site 704. The zonation is based on first and last appearances of globorotalids, principally Globoconella species, which are indigenous to temperate surface-water masses. Most of the first and last appearances at ODP Site 704 are diachronous with those in the warmer temperate to subtropical South Atlantic, North Atlantic, and South Pacific oceans.

The upper Miocene, upper Pliocene, and Quaternary sequences are punctuated by frequent incursions of subantarctic and polar assemblages of planktonic foraminifers. I assume that the appearance of an assemblage dominated by sinistral Neogloboquadrina pachyderma means that the Polar Front has migrated northward, but I do not know its position north or south of the site based on this preliminary work. The upper Miocene sequence contains five incursions between 6.5 and $5 \mathrm{Ma}$ and the upper Pliocene and Quaternary sequence contains 16 events since $2.47 \mathrm{Ma}$. These are minimum estimates because the number of observed events will probably increase with higher sample density and use of quantitative methods to reveal more subtle events.
\end{abstract}

\section{INTRODUCTION}

Late Cenozoic biostratigraphy of subantarctic regions is poorly defined because few sequences are available and few of these sequences are also calibrated to an absolute time scale. Correlation to an absolute time scale is essential in the subantarctic province because first and last appearances of planktonic foraminiferal species are likely to be migrational events that are diachronous with appearances in temperate and subtropical biogeographic provinces of the oceans.

The purpose of this paper is to (1) detail subantarctic planktonic foraminiferal biostratigraphy in the east Atlantic quadrant of the Southern Ocean during the Quaternary, Pliocene, and latest Miocene, (2) calibrate first and last appearances of planktonic foraminiferal species of the subantarctic to the geomagnetic polarity time scale, and 3) test the sequences for sensitivity to migrations of the Polar Front. This work paves the way for paleoceanographic, biogeographic, and evolutionary studies of the promising high-latitude, carbonate-rich Site 704 of the Ocean Drilling Program (ODP).

\section{METHODS}

Samples from Hole 704A were prepared by Allen and Warnke (this volume) and are identical to those used in their study. Samples from Hole 704B were selected from the data set of Müller et al. (this volume) and were prepared as described therein. Both sets of prepared samples consist of the $>63-\mu \mathrm{m}$ size fraction. To facilitate microscopic inspection of planktonic foraminifers, samples from Hole 704A were further subdivided into two size fractions, a 63- to $250-\mu \mathrm{m}$ fraction and a $>250-\mu \mathrm{m}$ fraction. I recorded the species present in both fractions and combined the data on a range chart. I determined the dominant genus or codominant genera in the $>250-\mu \mathrm{m}$ fraction by visual inspection, and I counted the ratio of sinistral to dextral forms of Neogloboquadrina

\footnotetext{
${ }^{1}$ Ciesielski, P. F., Kristoffersen, Y., et al., 1991. Proc. ODP, Sci. Results, 114: College Station, TX (Ocean Drilling Program).

${ }^{2}$ Center for Marine Science, The University of Southern Mississippi, Stennis Space Center MS 39529.
}

pachyderma. Because few specimens in samples from Hole 704B were larger than $250 \mu \mathrm{m}$, I viewed the $>63-\mu \mathrm{m}$ fraction to determine the species present and determined the most common genus or codominant genera in the $>150-\mu \mathrm{m}$ fraction.

Ages listed on all tables and in the manuscript are from a preliminary age model made in 1989 by interpolation between magnetostratigraphic and diatom datums. In January 1990, P.F. Ciesielski (pers. comm.) provided a revised age model for Site 704 in which the depths of datums are slightly different from those in the 1989 model. The differences in depth are shown on Table 1. The depths of five datums have changed by more than $1 \mathrm{~m}$ and less than $2.75 \mathrm{~m}$. The slight differences in estimated ages of samples generated by the 1990 model are insignificant for the purposes of this manuscript.

\section{LOCALITY}

Site 704 lies at $46^{\circ} 52.76^{\prime} \mathrm{S}, 07^{\circ} 25.23^{\prime} \mathrm{E}$, on the southern Meteor Rise in $2532 \mathrm{~m}$ of water. Seismic units in the region are gently folded, and the folds increase in amplitude downsection. The folds apparently formed as the result of differential compaction and tectonic movements rather than by largescale sliding because the folds lie on flat basement. The site rests in the axis of a gentle syncline, where the thick upper seismic units promise a thick sequence of Neogene-age sediments.

Site 704 was located near the Polar Front on Meteor Rise in the hope that the front had migrated across the region during periods of climatic change and that the migrational events were recorded in the sedimentary sequence. Subantarctic Surface Water (SSW) overlies Site 704 at present. SSW is bounded by the Subtropical Convergence approximately $5^{\circ}$ north of Site 704 and by the Antarctic Convergence Zone approximately $2.5^{\circ}$ south of the site (Lutjeharms and Valentine, 1984). The position of the Antarctic Convergence is constrained bathymetrically south of Africa and moves little compared with positions in other sectors of the Southern Ocean (Gordon, 1967, 1971). For example, during the last glacial maximum the Polar Front advanced no more than $4^{\circ}$ in the eastern Atlantic, compared with $7^{\circ}$ in the western Atlantic 
Table 1. Comparison of age and depth of datums used to calculate sample ages in this study with the 1990 age model (Hailwood and Clement this volume).

\begin{tabular}{|c|c|c|c|c|}
\hline & \multirow[b]{2}{*}{$\begin{array}{l}\text { Age } \\
(\mathrm{Ma})\end{array}$} & \multirow[b]{2}{*}{ Reference $^{\mathrm{a}}$} & \multicolumn{2}{|c|}{ Depth (mbsf) } \\
\hline & & & This study & $\begin{array}{c}\text { Revised } \\
\text { (January 1990) }\end{array}$ \\
\hline \multicolumn{5}{|l|}{ Hole 704A } \\
\hline LAD Hemidiscus karstenii & 0.195 & 1 & 1.14 & 1.14 \\
\hline LAD Actinocyclus ingens & 0.62 & 2 & 15.15 & 13.25 \\
\hline Brunhes/Matuyama boundary & 0.73 & 3 & 34.51 & 34.51 \\
\hline Top Jaramillo Subchron & 0.91 & 3 & 40.97 & $b_{38.41}$ \\
\hline Base Jaramillo Subchron & 0.98 & 3 & 44.66 & $\mathrm{~b}_{44.27}$ \\
\hline Top Olduvai Subchron & 1.66 & 3 & 87.40 & 89.09 \\
\hline LAD Coscinodiscus kolbei & 1.89 & 4 & 100.25 & Not used \\
\hline Matuyama/Gauss boundary & 2.47 & 3 & 168.72 & 168.45 \\
\hline Top Kaena Subchron & 2.92 & 3 & 176.70 & 176.10 \\
\hline Base Kaena Subchron & 2.99 & 3 & 177.98 & 177.80 \\
\hline Top Mammoth Subchron & 3.08 & 3 & 178.96 & 179.10 \\
\hline Base Mammoth Subchron & 3.18 & 3 & 181.13 & 181.50 \\
\hline Gauss/Gilbert boundary & 3.40 & 3 & 186.69 & 186.65 \\
\hline Top Cochiti Subchron & 3.88 & 3 & 195.80 & 198.55 \\
\hline Base Cochiti Subchron & 3.97 & 3 & 201.94 & 201.95 \\
\hline Top Nunivak Subchron & 4.10 & 3 & 204.19 & 204.20 \\
\hline Base Nunivak Subchron & 4.24 & 3 & 210.29 & 210.35 \\
\hline Top Sidufjall Subchron & 4.40 & 3 & 211.99 & 212.00 \\
\hline Base Sidufjall Subchron & 4.47 & 3 & 213.22 & 213.25 \\
\hline Top Thvera Subchron & 4.57 & 3 & 217.29 & 215.40 \\
\hline Base Thvera Subchron & 4.77 & 3 & 219.44 & 219.45 \\
\hline Gilbert/C3AN boundary & 5.35 & 3 & 224.89 & Not recognized \\
\hline \multicolumn{5}{|l|}{ Hole 704B } \\
\hline Top Sidufjall Subchron & 4.40 & 3 & 212.00 & Not recognized \\
\hline Base Sidufjall Subchron & 4.47 & 3 & 214.00 & Not recognized \\
\hline Top Thvera Subchron & 4.57 & 3 & 215.30 & Not recognized \\
\hline Base Thvera Subchron & 4.77 & 3 & 219.45 & Not recognized \\
\hline C3AN/Gilbert boundary & 5.35 & 3 & 224.60 & 224.76 \\
\hline C3AN.3 & 5.53 & 3 & 231.00 & 231.04 \\
\hline C3AN.6 & 5.68 & 3 & 234.00 & 233.84 \\
\hline C3AR/C3AN boundary & 5.89 & 3 & 241.50 & 241.62 \\
\hline C3AR.6 & 6.37 & 3 & 252.20 & 251.25 \\
\hline C3AR.75 & 6.50 & 3 & 257.50 & 256.75 \\
\hline $\mathrm{C} 4 \mathrm{~N} / \mathrm{C} 3 \mathrm{AR}$ boundary & 6.70 & 3 & 259.50 & 259.50 \\
\hline C4N.1 & 6.78 & 3 & 264.50 & 264.29 \\
\hline C4N.2 & 6.85 & 3 & 265.50 & 265.79 \\
\hline C4N.8 & 7.28 & 3 & 267.50 & 267.29 \\
\hline C4N.9 & 7.35 & 3 & 270.20 & 270.82 \\
\hline
\end{tabular}

Ocean (Hays et al., 1976). Despite the limited movement of the front in this sector of the South Atlantic Ocean, the sequence at Site 704 is likely to record frontal migrations because of its ideal location. In support of this hypothesis, radiolarian assem blages from piston cores indicate that the site was beneath the Antarctic Convergence Zone during the last glacial maximum (18,000 yr B.P.; Hays et al., 1976).

At present, Site 704 lies beneath the subantarctic biogeographic province of planktonic foraminifers that is characterized by abundant Neogloboquadrina pachyderma (Ehrenberg) and Globigerina bulloides d'Orbigny. North of the site, Neogloboquadrina dutertrei (d'Orbigny) is abundant in waters warmer than $15^{\circ} \mathrm{C}$, and Globorotalia inflata occurs commonly in assemblages in waters near $15^{\circ} \mathrm{C}$. Near the site, $G$. bulloides reaches peak abundances in waters near $5^{\circ}$ to $10^{\circ} \mathrm{C}$, and south of the site, $N$. pachyderma dominates the fauna in waters cooler than $5^{\circ} \mathrm{C}$ (Bé and Tolderlund, 1971). In general, the geographic ranges of species in the South Atlantic Ocean are similar to those in the South Pacific Ocean (Parker and Berger, 1971). The temperate assemblage characterized by $G$. inflata is distinctly different from the polar assemblage, which is dominated by sinistral $N$. pachyderma, a relationship that facilitates paleoceanographic interpretation.

\section{LITHOSTRATIGRAPHY}

The upper Miocene to Quaternary sequences considered in this study (Table 2) comprise four lithostratigraphic subunits within Unit I. Subunit IA is highly variable in color and lithology at intervals of about 20 to $100 \mathrm{~cm}$. The pelagic sediment consists of sharply bounded layers of diatom ooze alternating with carbonate-enriched diatom ooze and calcareous ooze. Subunit IB also consists of mixed carbonate and siliceous ooze, but the sequence is slightly more enriched in carbonate than Subunit IA. Subunit IC has two divisions. Subunit $\mathrm{IC}_{1}$ is enriched in carbonate and fairly homogeneous in color, whereas the variable color and lithology and enrichment by diatom ooze of Subunit $\mathrm{IC}_{2}$ are similar to Subunits IA and IB. Subunit ID consists of nannofossil ooze.

\section{RESULTS: DESCRIPTION OF PLANKTONIC FORAMINIFERAL FAUNA}

The assemblage at the top of Hole $704 \mathrm{~A}$, from 0.0 to 16.86 $\mathrm{m}$ below seafloor (mbsf) (Table 3), is typical of modern assemblages of the subantarctic and polar South Atlantic Ocean (Bé and Tolderlund, 1971) and consists of abundant Globigerina bulloides and its phenotypes or Neogloboquad- 
Table 2. Comparison of lithostratigraphic units and informal assemblage zones, Site 704 .

\begin{tabular}{|c|c|c|c|c|}
\hline \multicolumn{2}{|c|}{ I. ithostratigraphic unit } & \multirow[b]{2}{*}{ Cores studied } & \multicolumn{2}{|c|}{ Assemblage zone } \\
\hline Unit & Depth (mbsf) & & Zone & Depth (mbsf) \\
\hline \multicolumn{5}{|c|}{ Hole 704A } \\
\hline $\begin{array}{l}\mathrm{IA} \\
\mathrm{II} \\
\mathrm{IC} \\
\mathrm{IC} \\
\mathrm{IC}_{1} \\
\mathrm{IC}_{2}\end{array}$ & $\begin{array}{r}0.0-102.2 \\
102.2-178.2 \\
178.2-254.2 \\
178.2-222.2 \\
222.2-254.2\end{array}$ & $\begin{array}{l}1 \mathrm{H} \text { to } 11 \mathrm{H} \\
12 \mathrm{H} \text { to } 19 \mathrm{X} \\
20 \mathrm{X} \text { to } 27 \mathrm{X} \\
20 \mathrm{X} \text { to } 24 \mathrm{X}-5 \\
24 \mathrm{X}-5 \text { to } 25 \mathrm{X}-6\end{array}$ & $\begin{array}{l}\mathrm{A}_{1}+\mathrm{A}_{2} \\
\mathrm{~B} \\
\mathrm{C} \\
\mathrm{C}_{1} \\
\mathrm{C}_{2}\end{array}$ & $\begin{array}{r}0-101.82 \\
102.92-165.92 \\
167.42-234.22 \\
167.42-217.50 \\
219.00-261.20\end{array}$ \\
\hline \multicolumn{5}{|c|}{ Hole 704B } \\
\hline $\begin{array}{l}\text { IC } \\
\text { IC } \\
\text { IC } \\
\text { ID }\end{array}$ & $\begin{array}{l}175.7-251.7 \\
175.7-219.0 \\
219.0-251.7 \\
251.7-451.2\end{array}$ & $\begin{array}{l}24 \mathrm{X} \text { to } 27 \mathrm{X} \\
24 \mathrm{X} \text { to } 24 \mathrm{X}-4 \\
24 \mathrm{X}-4 \text { to } 27 \mathrm{X}-\mathrm{CC} \\
28 \mathrm{X}\end{array}$ & $\begin{array}{l}\mathrm{C} \\
\mathrm{C}_{1} \\
\mathrm{C}_{2} \\
\mathrm{D}\end{array}$ & $\begin{array}{l}214.50-251.70 \\
214.50-219.90 \\
221.90-251.70 \\
253.10-261.20\end{array}$ \\
\hline
\end{tabular}

rina pachyderma, with common Globigerina quinqueloba, Globorotalia inflata, and Globigerinita glutinata and rare occurrences of Globorotalia scitula, Globorotalia crassaformis, and Globorotalia truncatulinoides, the marker species of the Pleistocene in low latitudes of the Atlantic Ocean. G. truncatulinoides first occurs in Sample 114-704A-2H-1, $64-68 \mathrm{~cm}$, and Globorotalia crassula last occurs in Sample $114-704 \mathrm{~A}-1 \mathrm{H}-5,70-74 \mathrm{~cm}$.

The assemblage in the middle interval at Hole $704 \mathrm{~A}$ is mostly dominated by Globorotalia puncticulata and its subspecies, which last occur in Sample 114-704A-2H-7, 30-34 $\mathrm{cm}$, and first occur in Sample 114-704A-23X-3, 128-132 cm. The assemblage bears $N$. pachyderma, $G$. quinqueloba, $G$. glutinata, and Globigerinella calida with rare and sporadic occurrences of G. crassaformis and Globorotalia theyeri. G. crassula first occurs in Sample 114-704A-8H-2, 69-73 cm, and ranges to near the top of the section at the site; $G$. inflata first occurs in Sample 114-704A-17X-1, 70-74 cm, and recurs sporadically upsection to the top of the core. Globorotalia $\mathrm{cf}$. pliozea first occurs in Sample 114-704A-24X-2, 128-132 cm, and occurs commonly up to Sample 114-704A-6H-5, 68-72 $\mathrm{cm}$. The distinctive species Globigerina cariacoensis ranges from Samples 114-704A-21X-3, 8-12 cm, to 114-704A-3H-5, $96-100 \mathrm{~cm}$. Globorotalia $\mathrm{cf}$. margaritae, which grades morphologically into $G$. theyeri, occurs in Samples 114-704A-21X$2,8-12 \mathrm{~cm}$, to $114-704 \mathrm{~A}-22 \mathrm{X}-1,39-43 \mathrm{~cm}$.

The ranges of species characteristic of the underlying assemblage overlap with the ranges of species of the association described in the preceding text. Specifically, Globorotalia cibaoensis, Globorotalia juanai, and Globigerina woodi last occur above the base of the overlying association, in Sample 114-704A-23X-3, 128-132 cm, where Globorotalia puncticulata first appears. These species extend below the overlying association to the lowermost sample examined from this hole. Globorotalia sphericomiozea occurs in the lower portion of the hole, from Sample 114-704A-23X-3, 128-132 cm, to the bottom. Other important but long-ranging species of this deepest association include $N$. pachyderma, G. quinqueloba, G. glutinata, and Globigerina bulloides. Assemblages beneath 218 mbsf in the hole suffer dissolution and bear only a few robust specimens.

Samples examined in Hole 704B (Table 4) appear to underlie closely the sequence described from Hole 704A. Samples 114-704B-24X-1, 80-82 cm, to 114-704B-24X-4, 80$82 \mathrm{~cm}$, bear the same species and are dominated by Globorotalia, as is the bottommost association of Hole 704A. Beneath this association are two others. The upper one is characterized by Globorotalia miozea, which ranges from Samples 114$704 \mathrm{~B}-24 \mathrm{X}-4,80-82 \mathrm{~cm}$, to $114-704 \mathrm{~B}-27 \mathrm{X}-3,86-90 \mathrm{~cm}$.
Globorotalia conoidea occurs near the base of the range of $G$. miozea in Samples 114-704B-26X-5, 50-54 cm, 114-704B$27 \mathrm{X}-2,110-112 \mathrm{~cm}$, and 114-704B-27X-4, 50-52 cm. The hirsutellid species G. cibaoensis, G. juanai, G. theyeri, and $G$. scitula, along with the globoconellid Globorotalia panda, occur sporadically throughout this interval and comprise their own association beneath the first occurrence of $G$. miozea.

Intermixed with samples bearing globorotalids are samples of low diversity, poor preservation, and small foraminiferal numbers. The depauperate samples are dominated by Globigerina or Neogloboquadrina and may record Miocene advances of polar waters to the Meteor Rise. Tentative age assignments of these events based on the 1989 age model (see Table 1) are in Table 4.

\section{ZONATION}

The zonations of Jenkins $(1967,1971)$ and Jenkins and Srinivasan (1986) best subdivide the subantarctic sequences. Most zonal boundaries are likely diachronous with those of temperate waters. In the zonation cited in the following, LA = last appearance and $\mathrm{FA}=$ first appearance.

\section{Globorotalia miotumida Zone (Jenkins, 1967)}

Base. LA Globorotalia mayeri mayeri.

Top. FA Globorotalia sphericomiozea or Globorotalia conomiozea .

Remarks. The G. miotumida Zone ranges from Samples 114-704B$28 \mathrm{X}-7,49-51 \mathrm{~cm}$, which was the lowest sample examined, to 114-704B-25X-2, 80-82 cm.

\section{Globorotalia sphericomiozea Zone (Jenkins, 1967)}

Base. FA of nominate taxon.

Top. LA of nominate taxon.

Remarks. The definition of the top of this zone is modified from that in Jenkins (1967) and is consistent with that in Jenkins and Srinivasan (1986). The zone occurs in both holes at the site, extending from Sample 114-704B-25X-1, 20-22 cm, to the top of the studied interval, and from the base of the studied sequence to Sample 114-704A-23X-3, 128-132 cm.

Globorotalia puncticulata Zone (Jenkins and Srinivasan, 1986)

Base. LA of Globorotalia sphericomiozea.

Top. FA of Globorotalia inflata.

Remarks. The G. puncticulata Zone extends from Samples 114-704A$23 \mathrm{X}-2,128-132 \mathrm{~cm}$, to $114-704 \mathrm{~A}-17 \mathrm{X}-2,70-74 \mathrm{~cm}$.

Globorotalia inflata Zone (Jenkins and Srinivasan, 1986)

Base. FA of nominate taxon.

Top. FA of Globorotalia truncatulinoides.

Remarks. The $G$. inflata zone extends from Samples 114-704A-17-1, $70-74 \mathrm{~cm}$, to $114-704 \mathrm{~A}-2 \mathrm{H}-2,64-68 \mathrm{~cm}$.

Globorotalia truncatulinoides Zone (Jenkins, 1975; Jenkins and Srinivasan, 1986)

Base. FA of nominate taxon.

Top. Not defined.

Remarks. The G. truncatulinoides Zone extends from Sample 114$704 \mathrm{~A}-2 \mathrm{H}-1,64-68 \mathrm{~cm}$, to the top of the hole.

\section{FIRST AND LAST APPEARANCES OF SPECIES}

First and last appearances of planktonic foraminiferal species in the Atlantic sector of the subantarctic are in several instances diachronous with appearances in other water masses and in other oceans. Discussed in the following are appearances of selected species used to zone Site 704 (Table 5).

Globorotalia truncatulinoides appeared at Meteor Rise about $400,000 \mathrm{yr}$ ago, later than in the North Atlantic Ocean (Weaver and Clement, 1986, 1987), the subtropical South Pacific Ocean (Dowsett, 1988), and the South Atlantic Ocean (Berggren et al., 1983). Its appearance in the northern subant- 


\section{A. BRUNNER}

Table 3. Planktonic foraminifers from Hole 704A, Meteor Rise.

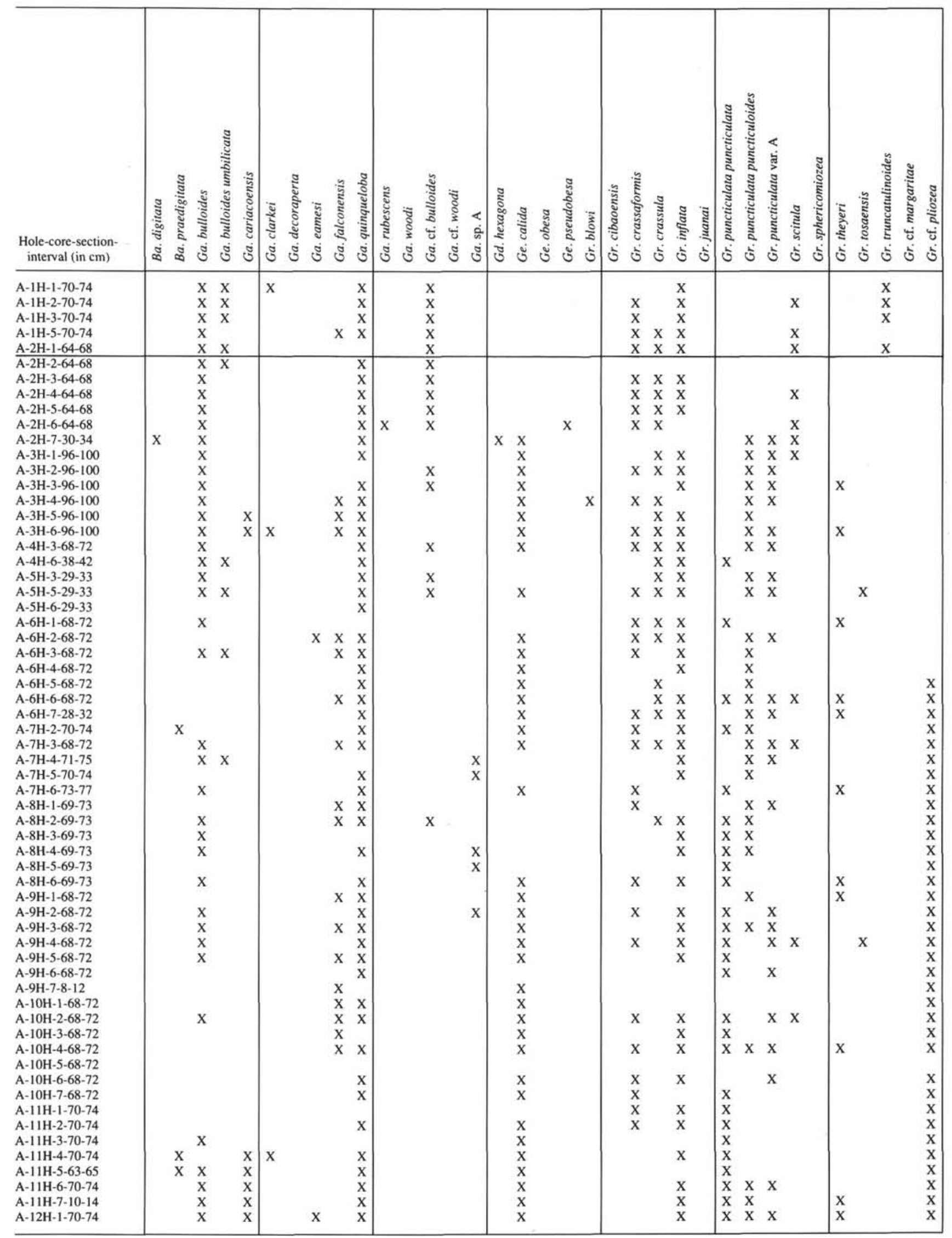

Note: $\mathrm{X}=$ present

Note: Species arranged alphabetically. 
Table 3 (continued).

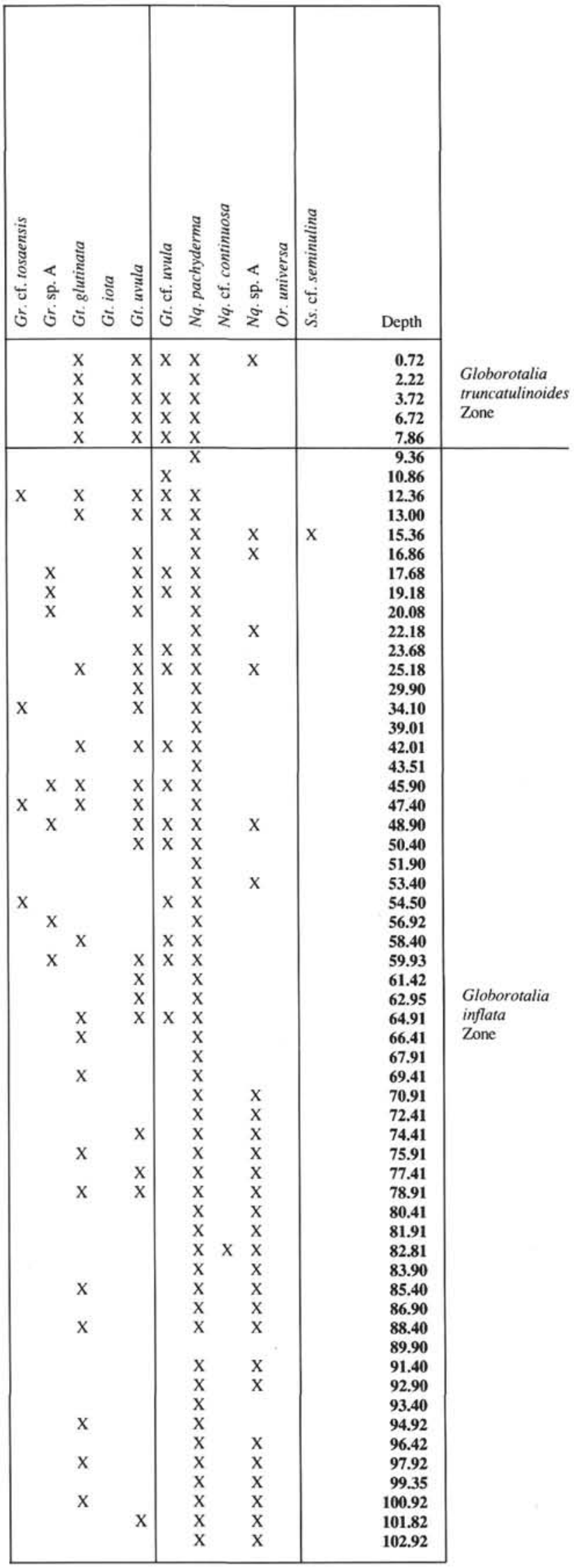

arctic of the South Atlantic Ocean predates that in the northern subantarctic Pacific Ocean by about 100,000 yr (Kennett, 1970).

Globorotalia inflata appeared at Meteor Rise at about the same time it appeared in the subtropical and temperate North Atlantic Ocean (Weaver and Clement, 1986, 1987), at about $2.3 \mathrm{Ma}$, but the appearance is later by about 1 to $2 \mathrm{~m}$.y. than that reported in the South Atlantic Ocean (Berggren et al., 1983; Hodell and Kennett, 1986). It is possible that reported disconformities, dissolution, and downhole contamination have confused the proper age assignment of its first appearance in the subtropical South Atlantic waters (Poore, 1984; Scott, 1983; Berggren et al., 1983). G. inflata appeared in the Pacific Ocean about 1 m.y. earlier than at Site 704 (Hodell and Kennett, 1986).

In contrast to the subtropical South Atlantic Ocean, Globorotalia puncticulata and its subspecies are the dominant globorotalids in the Pliocene to middle Pleistocene sections of the site. The taxon last appeared in the middle Pleistocene at Meteor Rise about $628,000 \mathrm{yr}$ ago, which is similar to its last appearance in the South Pacific Ocean (Hornibrook, 1982). It first appeared about $4.3 \mathrm{~m} . \mathrm{y}$. ago at Meteor Rise, 1 m.y. later than at some subtropical and temperate sites of the South Pacific Ocean (Hodell and Kennett, 1986) and a few hundred thousand years to $1 \mathrm{~m} . \mathrm{y}$. later than in the subtropical South Atlantic Ocean (Hodell and Kennett, 1986).

Globorotalia crassaformis first appeared 3.9 m.y. ago, about 375,000 yr later than $G$. puncticulata, at Meteor Rise. The age of the first appearance of $G$. crassaformis was close to that of the warm subtropical South Pacific Ocean, but 1 m.y. younger than its age of appearance in the temperate South Pacific Ocean (Hodell and Kennett, 1986). The species appeared at midlatitudes in the South Atlantic Ocean a little more than 1 m.y. (Poore et al., 1983) before it appeared at Meteor Rise. However, G. crassaformis is very rare, although persistent, at Site 704, which makes accurate recognition of its first occurrence difficult.

Globorotalia sphericomiozea first appeared 5.2 m.y. ago at Meteor Rise, a date consistent with those from the subtropical and temperate South Pacific Ocean (Hodell and Kennett, 1986). It last appeared $4.3 \mathrm{~m} . \mathrm{y}$. ago, prior to the final appearance of Globorotalia juanai at $3.5 \mathrm{~m} . \mathrm{y}$. The extinction sequence is similar to that at Deep Sea Drilling Project (DSDP) Site 284 in the South Pacific Ocean. Scott (1982) reported primitive forms of G. sphericomiozea in the subtropical Atlantic Ocean, but commonly the taxon is not reported or it is lumped with $G$. puncticulata (Poore and Berggren, 1975).

\section{SUCCESSION OF DOMINANT GENERA}

Three genera dominate samples from Site 704: Globigerina, Globorotalia, and Neogloboquadrina (Fig. 1 and Table 6). The Neogloboquadrina assemblage consists of sinistral Neogloboquadrina pachyderma and very rare occurrences of other neogloboquadrinids. At Hole 704A, most samples contain assemblages dominated by Globorotalia (75 samples), followed by Neogloboquadrina ( 21 samples), and Globigerina (7 samples). Genera are codominant in some samples. The most common codominance pair is Globigerina and Globorotalia (12 samples), followed by Globorotalia and Neogloboquadrina ( 7 samples) and Neogloboquadrina and Globigerina (2 samples). Five samples bear near equal numbers of all three genera. At Hole 704B, either Globigerina or Neogloboquadrina dominates most samples (36), whereas Globorotalia dominates or codominates assemblages of only five of 41 samples examined. 


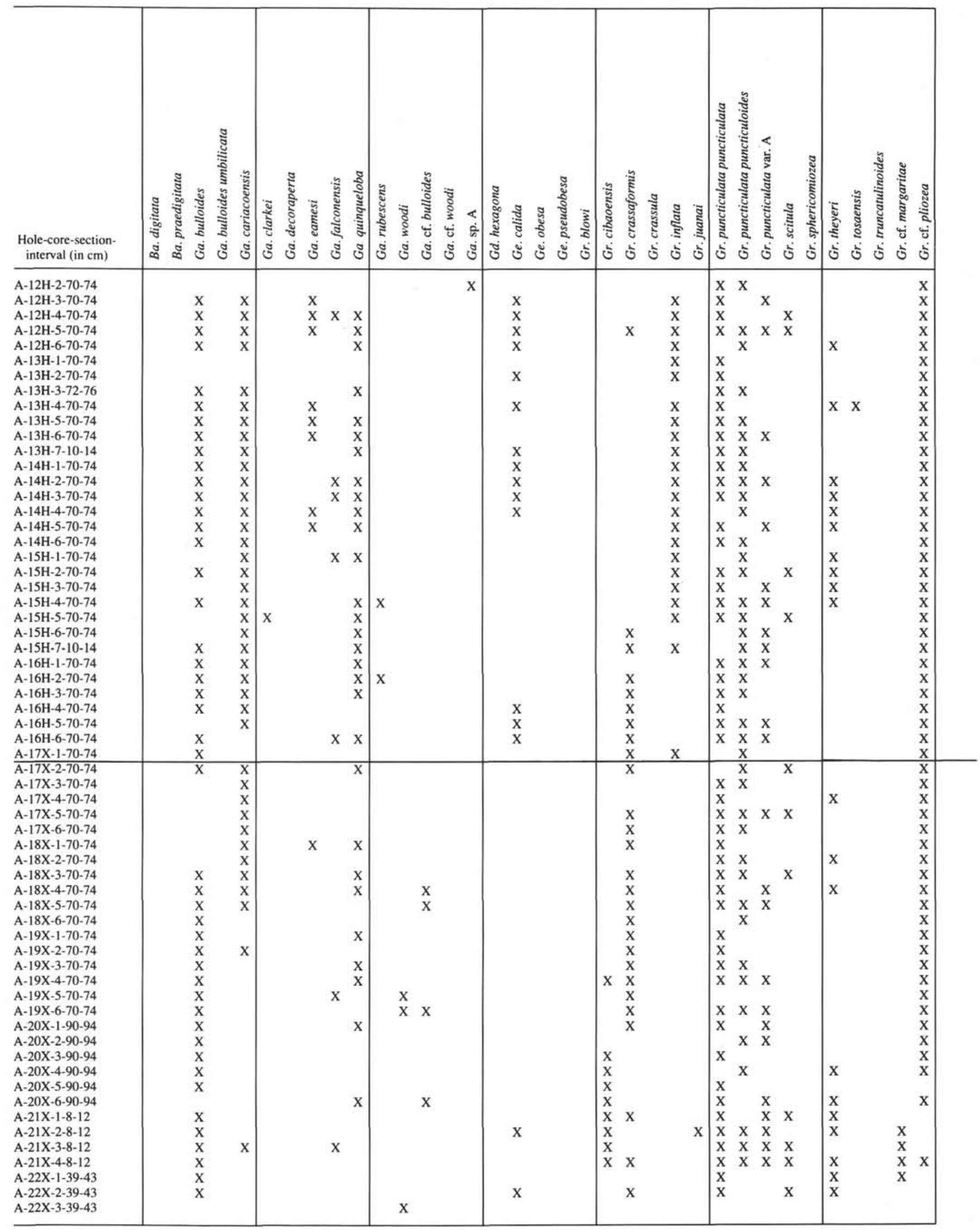

Note: $\mathrm{X}=$ present 
Table 3 (continued).

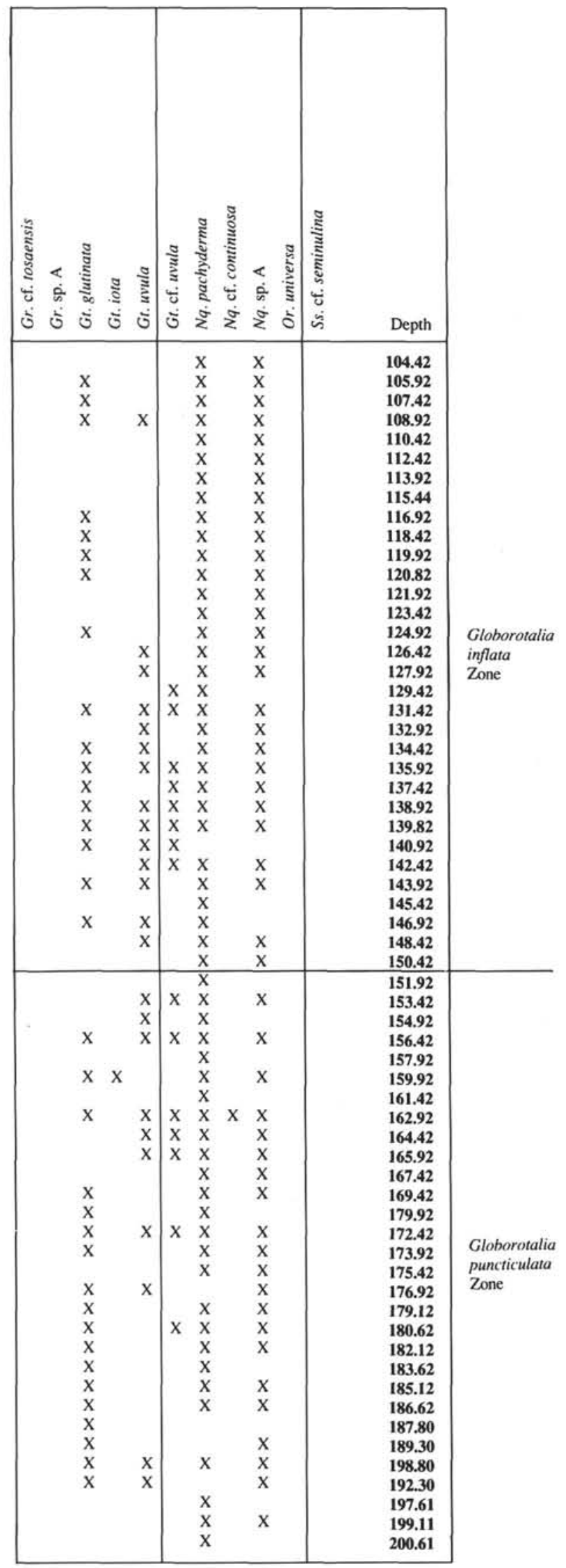

The pattern of assemblage succession can be divided into informal assemblage zones: five zones and subzones in Hole $704 \mathrm{~A}$ and three in Hole 704B (Fig. 1 and Table 2). At Hole $704 \mathrm{~A}$, the top zone, $\mathrm{A}$, is divided into two parts, subzones $\mathrm{A}_{1}$ and $A_{2}$. Subzone $A_{1}$, which ranges from 0 to $17 \mathrm{mbsf}$, is dominated by Globigerina interspersed with some Neogloboquadrina. The underlying subzone, $\mathrm{A}_{2}$, is dominated by Globorotalia and Neogloboquadrina and extends from 17 to 102 mbsf. Beneath zone A lies zone B, in which most samples are dominated by Globorotalia interspersed with Globigerina and Neogloboquadrina. Zone B bottoms at $166 \mathrm{mbsf}$. The next deepest zone, $C$, is divided into two parts. Subzone $C_{1}$ at Hole 704A consists of Globorotalia and ranges in depth from 166 to 218 mbsf. Samples below 218 mbsf contain too few fossils to determine dominance, and I refer this interval of poor carbonate preservation to subzone $C_{2}$.

At Hole 704B (Fig. 1 and Table 2), the top zone is dominated by Globorotalia and is referable to subzone $\mathrm{C}_{1}$. The middle zone is characterized by barren intervals and poorly preserved samples with either Neogloboquadrina or Globigerina and is referable to subzone $\mathrm{C}_{2}$. The bottom interval is characterized by well-preserved samples dominated by Neogloboquadrina or Globigerina and is assigned to zone D.

The boundaries of the assemblage zones described here correspond closely to the boundaries of the lithostratigraphic units (Table 2). The correspondence is natural because the sediment is primarily biogenic and lithology and fossil assemblages are both controlled by pelagic environment. The boundary between informal assemblage zones $\mathrm{B}$ and $\mathrm{C}$ does not correspond to a lithologic boundary but is distinguished by the first large input of ice-rafted, sand-size mineral grains (Allen and Warnke, this volume) and a marked increase in oxygen isotope anomaly (Müller et al., this volume).

Assemblages dominated by Neogloboquadrina pachyderma occur in alternation with other assemblages in the upper Miocene and above the first abundant ice-rafted debris at 167.42 mbsf (2.46 Ma), whereas the Globorotalia assemblage persists throughout the lower Pliocene. I assume that the appearance of the Neogloboquadrina assemblage marks the incursion of polar waters and the northward migration of the Polar Front. Five incursions are recorded within the upper Miocene samples, and 16 migrations are revealed in the upper Pliocene and Quaternary samples (Fig. 1 and Table 6). More migrational events are likely to be revealed by finer sampling and a quantitative census of specimens which will reveal subtle variations.

The ratio between sinistral and dextral forms of Neogloboquadrina pachyderma is typically proportional to temperature and should serve as second line of evidence to support migration of warm and cool water masses. Sinistral forms of $N$. pachyderma, however, dominate all samples that bear the species. In samples from the tops of cores from the temperate South Pacific Ocean, sinistral forms comprise greater than $90 \%$ of the population of $N$. pachyderma in the southern half of the waters bounded by the Antarctic and Subtropical convergences (Kennett, 1968). Throughout the late Miocene and Quaternary, Site 704 apparently lay south of the water mass in which coiling forms are sensitive to temperature.

\section{TAXONOMIC NOTES}

Beella digitata (Brady), 1884

Beella praedigitata (Parker), 1967

Globigerina bulloides d'Orbigny, 1826

Globigerina bulloides umbilicata Orr and Zaitzeff, 1971 
Table 3 (continued).

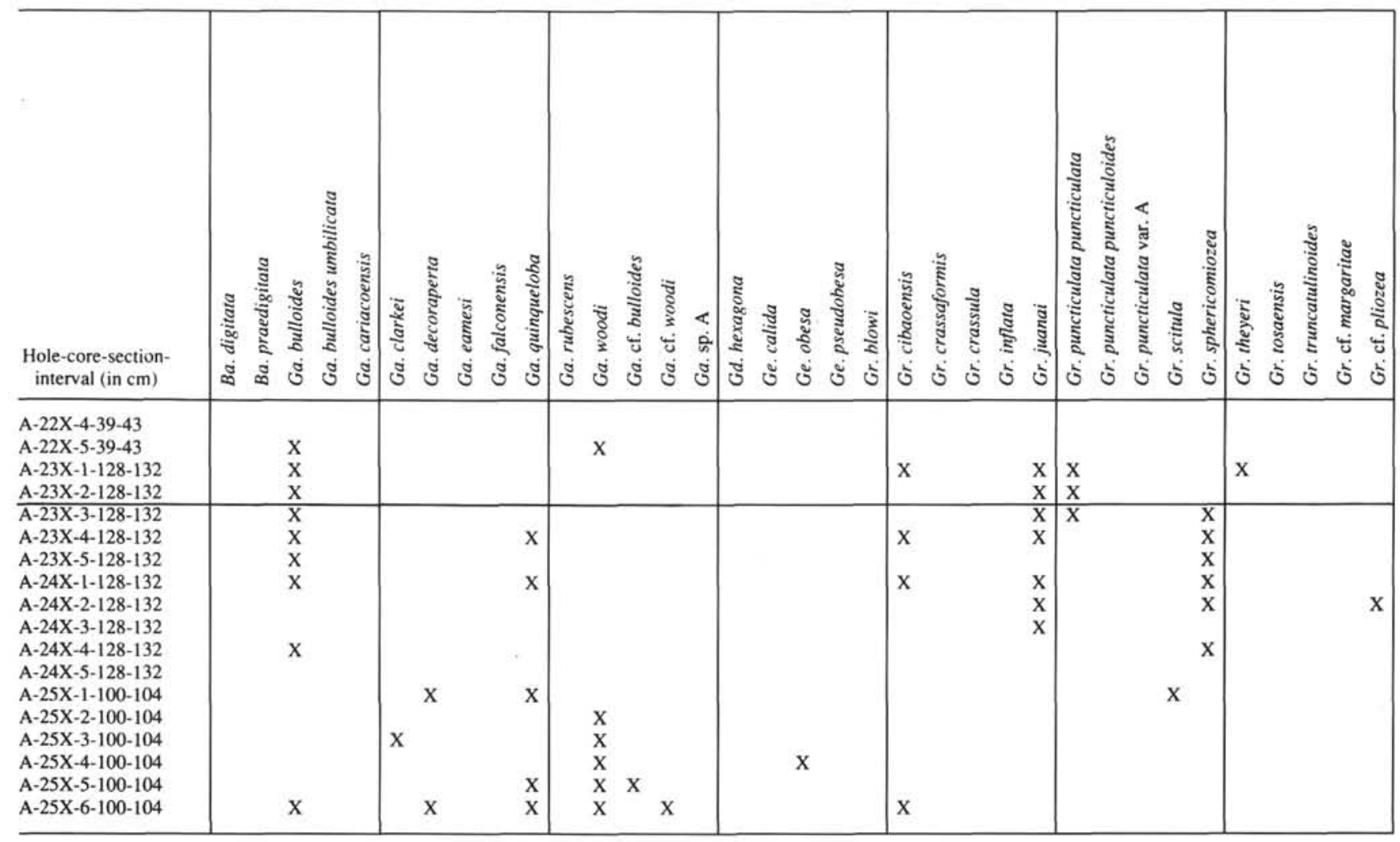

Note: $\mathbf{X}=$ present

Globigerina cf. bulloides. G. bulloides is highly variable in the studied section. These forms have an unusually compressed aperture. Some specimens have only three chambers in the final whorl.

Globigerina cariacoensis Rogl and Bolli, 1973. This form differs from $G$. bulloides in its high spire and, in this section, by its rugged, spiny texture and radially elongate chambers. The forms are similar to those in Poore and Berggren (1975; pl. 5, figs. 9-12) from DSDP Site 116 , at $57^{\circ} 30^{\prime} \mathrm{N}$ latitude in the North Atlantic Ocean. The taxon may be a form of Globigerina megastoma Earland, 1934, which was described from high latitude. Kennett and Srinivasan (1983) call G. megastoma a phenotype of $G$. bulloides.

Globigerina clarkei Rogl and Bolli, 1973

Globigerina decoraperta Takayanagi and Saito, 1962

Globigerina eamesi Blow, 1959

Globigerina falconesis Blow, 1959

Globigerina quinqueloba Natland, 1938

Globigerina rubescens Hofker, 1956

Globigerina woodi Jenkins, 1960

Globigerina cf. woodi

Globigerina sp. A. This taxon is identical to Globigerina sp. A illustrated in Poore (1979).

Globigerinella calida (Parker), 1962

Globigerinella obesa (Bolli), 1957

Globigerinella pseudobesa (Salvatorini), 1966

Globigerinita glutinata (Egger), 1893

Globigerinita iota Parker, 1962

Globigerinita uvula (Ehrenberg), 1861
Globigerinita cf. uvula. This taxon is similar to the highlatitude form of G. uvula illustrated in Parker (1962, pl. 8 , specimens 24,25 , and 26 ).

Globorotalia anfracta Parker, 1967

Globorotalia cibaoensis Bermudez, 1949. Scott (1983) does not distinguish this taxon from Globorotalia juanai at DSDP Site 284. I find that it is somewhat gradational with all the hirsutellids at Site 704 .

Globorotalia blowi (Thompson), 1973

Globorotalia conoidea Walters, 1965

Globorotalia crassaformis (Galloway and Wissler), 1927

Globorotalia crassula Cushman and Stewart, 1930

Globorotalia inflata d'Orbigny, 1839

Globorotalia juanai Bermudez and Bolli, 1969

Globorotalia margaritae Bolli and Bermudez, $1965 \mathrm{cf}$. margaritae. The specimens are gradational with Globorotalia theyeri.

Globorotalia miozea Finlay, 1939

Globorotalia panda Jenkins, 1960

Globorotalia $\mathrm{cf}$. pliozea. The form in Hole 704A differs from that described by Hornibrook (1982) in that this form has no keel. Its test shape, surface texture, aperture, and chamber shape are identical to the taxon described by Hornibrook (1982). The specimens at Hole 704A typically bear a thick secondary crust of calcite.

Globorotalia puncticulata puncticulata (Deshayes), 1832. Forms like those of figures $5 \mathrm{k}-5 \mathrm{q}$ of Hornibrook (1982) were noted.

Globorotalia puncticulata var. A. This form is like those of figures 5e and $5 f$ of Hornibrook (1982) and is believed to 
Table 3 (continued).

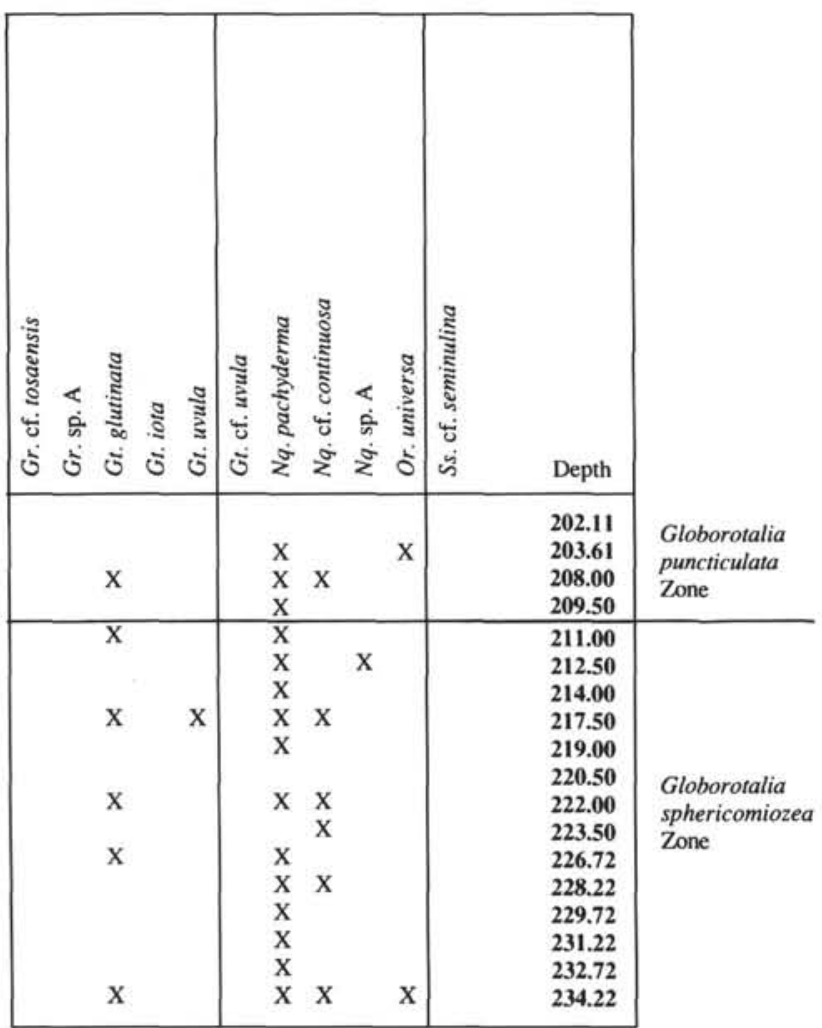

be a pregametogenic form of $G$. puncticulata puncticulata.

Globorotalia puncticulata puncticuloides Hornibrook, 1981. Of the two forms observed, one is like figure 5a of Hornibrook (1982) and the other is like figure 5c of Hornibrook (1982) and figures 7a and 7c of Hornibrook (1981). The form commonly appears to bear a rim when viewed with a light microscope, but no rim is evident under the scanning electron microscope.

Globorotalia scitula (Brady), 1882

Globorotalia sphericomiozea Walters, 1965

Globorotalia theyeri Fleisher, 1974

Globorotalia tosaensis Takayanagi and Saito, 1962

Globorotalia truncatulinoides (d'Orbigny), 1839

Globorotaloides hexagona (Natland), 1938

Neogloboquadrina cf. continuosa (Blow), 1959

Neogloboquadrina pachyderma (Ehrenberg), 1861

Orbulina universa d'Orbigny, 1839

Sphaeroidinellopsis cf. seminulina (Schwager), 1866

\section{ACKNOWLEDGMENTS}

I wish to thank Paul Ciesielski for inviting me to work on this project. Special thanks are due Dietz Warnke, Carl Allen, Paul Ciesielski, Danny Müller, and Dave Hodell for sharing samples and data with me. The SEM work was done in part at California State University, Hayward, with the help of Nancy Benson, in part at the Department of Biological Sciences of the University of Southern Mississippi with the help of Raymond Scheetz, and in part at the Gulf Coast
Research Laboratory in Ocean Springs, Mississippi, with the help of Bill Hawkins. I also thank the scientists who reviewed this manuscript; their suggestions were helpful and constructive. Finally, special thanks go to Lona Dearmont and Ted Moore for their help and advice.

\section{REFERENCES}

Bé, A.W.H., and Tolderlund, D. S., 1971. Distribution and ecology of living planktonic foraminifera in surface waters of the Atlantic and Pacific oceans. In Funnel, B. M., and Riedel, W. R. (Eds.), Micropaleontology of the Oceans: Cambridge (Cambridge Univ. Press), 105-149.

Berggren, W. A., Aubry, M.-P., and Hamilton, N., 1983. Neogene magnetobiostratigraphy of DSDP Site 516 (Rio Grande Rise, South Atlantic). In Barker, P. F., Carlson, R. L., Johnson, D. A., et al., Init. Repts. DSDP, 72: Washington (U.S. Govt. Printing Office), 675-713.

Berggren, W. A., Kent, D. V., and Van Couvering, J. A., 1985. The Neogene: part 2. Neogene geochronology and chronostratigraphy, In Snelling, N. J. (Ed.), The Chronology of the Geological Record. $10: 211-260$.

Burckle, L. H., 1982. First appearance datum of Hemidiscus karstenii in late Pleistocene of the subantarctic region. Ant. J. U.S., 17:142-143.

Ciesielski, P. F., 1983. The Neogene and Quatemary diatom biostratigraphy of subantarctic sediments, Deep Sea Drilling Project Leg 71. In Ludwig, W. J., Krasheninnikov, V. A., et al., Init. Repts. DSDP, 71: Washington (U.S. Govt. Printing Office), 635-665.

Dowsett, H. J., 1988. Diachrony of Late Neogene microfossils in the southwest Pacific Ocean: application of the graphic correlation method. Paleoceanography, 3:209-222.

Gordon, A. L., 1967. Structure of Antarctic Waters between $20^{\circ} \mathrm{W}$ and $170^{\circ}$ W. In Bushnell, V. C. (Ed.), Antarctic Map Folio Series, 6. 1971. Antarctic Polar Front Zone. In Reid, V. L. (Ed.), Antarctic Oceanology I: Am. Geophys. Union Antarct. Res. Ser., $15: 205-221$.

Hays, J. D., Lozano, J. A., Shackleton, N. J., and Irving, G., 1976. Reconstruction of the Atlantic and western Indian Ocean sectors of the 18,000 B. P. Antarctic Ocean. In Cline, R. M., and Hays, J. D. (Eds.), Investigations of Late Quaternary Paleoceanography and Paleoclimatology: Mem. Geol. Soc. Am., 145:337-372.

Hodell, D. A., and Kennett, J. P., 1986. Late Miocene-early Pliocene stratigraphy and paleoceanography of the South Atlantic and southwest Pacific oceans: a synthesis. Paleoceanography, 1:285-311.

Hornibrook, N. de B, 1981. Globorotalia (planktic Foraminiferida) in the late Pliocene and early Pleistocene of New Zealand. N.Z. J. Geol. Geophys., 24:263-292.

1982. Late Miocene to Pleistocene Globorotalia (Foraminiferida) from DSDP Leg 29, Site 284, southwest Pacific. N.Z. J. Geol. Geophys., 25:83-99.

Jenkins, D. G., 1967. Planktonic foraminiferal zones and new taxa from the lower Miocene to the Pleistocene of New Zealand. N.Z. J. Geol. Geophys., 10:1064-1078.

1971. New Zealand Cenozoic planktonic foraminifera. N.Z. Dept. Sci. Industr. Res., N.Z. Geol. Surv., Paleontol. Bull., 42:1-178.

Jenkins, D. G., and Srinivasan, M. S., 1986. Cenozoic planktonic foraminifers from the equator to the subantarctic of the southwest Pacific. In Kennett, J. P., von der Borch, C. C., et al., Init. Repts. DSDP, 90: Washington (U.S. Govt. Printing Office), 795-834.

Kennett, J. P., 1968. Latitudinal variation in Globigerina pachyderma (Ehrenberg) in surface sediments of the southwest Pacific Ocean. Micropaleontology, 14:305-318.

1970. Pleistocene paleoclimates and foraminiferal biostratigraphy in subarctic deep-sea cores. Deep-Sea Res., Part A, $17: 125-140$.

Kennett, J. P., and Srinivasan, M. S., 1983. Neogene Planktonic Foraminifera, A Phylogenetic Atlas: Stroudsburg, PA (Hutchinson Ross).

Lutjeharms, J.R.E., and Valentine, H. R., 1984. Southern Ocean thermal fronts south of Africa. Deep-Sea Res., Part A, 31:1461-1475.

Parker, F. L., 1962. Planktonic foraminiferal species in Pacific sediments. Micropaleontology, 8:219-254. 
Parker, F. L., and Berger, W. H., 1971. Faunal and solution patterns of planktonic foraninifera in surface sediments of the South Pacific. Deep-Sea Res., Part A, 18:73-107.

Poore, R. Z., 1979. Oligocene through Quaternary planktonic foraminiferal biostratigraphy of the North Atlantic: DSDP Leg 49. In Luyendyk, B. P., Cann, J. R., et al., Init. Repts. DSDP, 49: Washington (U.S. Govt. Printing Office), 447-517.

1984. Middle Eocene through Quaternary planktonic foraminifers from the southern Angola basin. In Hsü, K. J., LaBrecque, J. L., et al., Init. Repts. DSDP, 73: Washington (U.S. Govt. Printing Office), 429-448.

Poore, R. Z., and Berggren, W. A., 1975. Late Cenozoic planktonic foraminifera biostratigraphy and paleoclimatology of HattonRockall Basin: DSDP Site 116. J. Foraminiferal Res., 5:270-293.

Poore, R. Z., Tauxe, L., Percival, S. F., Jr., LaBrecque, J. L., Wright, R., Peterson, N. P., Smith, C. C., Tucker, P., and Hsü, K. J., 1983. Late Cretaceous-Cenozoic magnetostratigraphic and biostratigraphic correlations for the South Atlantic Ocean, DSDP Leg 73. Palaeogeogr., Palaeoclimatol., Palaeoecol., 42:127-148.

Scott, G. H., 1983. Biostratigraphy and histories of upper MiocenePliocene Globorotalia, South Atlantic and south west Pacific. Mar. Micropaleontol., 7:369-383.

Weaver, P.P.E., and Clement, B. M., 1986. Synchroneity of Pliocene planktonic foraminiferal datums in the North Atlantic. Mar. Micropaleontol., 10:295-307.

1987. Magnetobiostratigraphy of planktonic foraminiferal datums, DSDP Leg 94 North Atlantic. In Ruddiman, W. F., Kidd, R. B., et al., Init. Repts. DSDP, 94: Washington (U.S. Govt. Printing Office), 815-829.

Date of initial receipt: 4 April 1989

Date of acceptance: 28 February 1990

Ms 114B-183

Table 4. Planktonic foraminifers from Hole 704B, Meteor Rise.

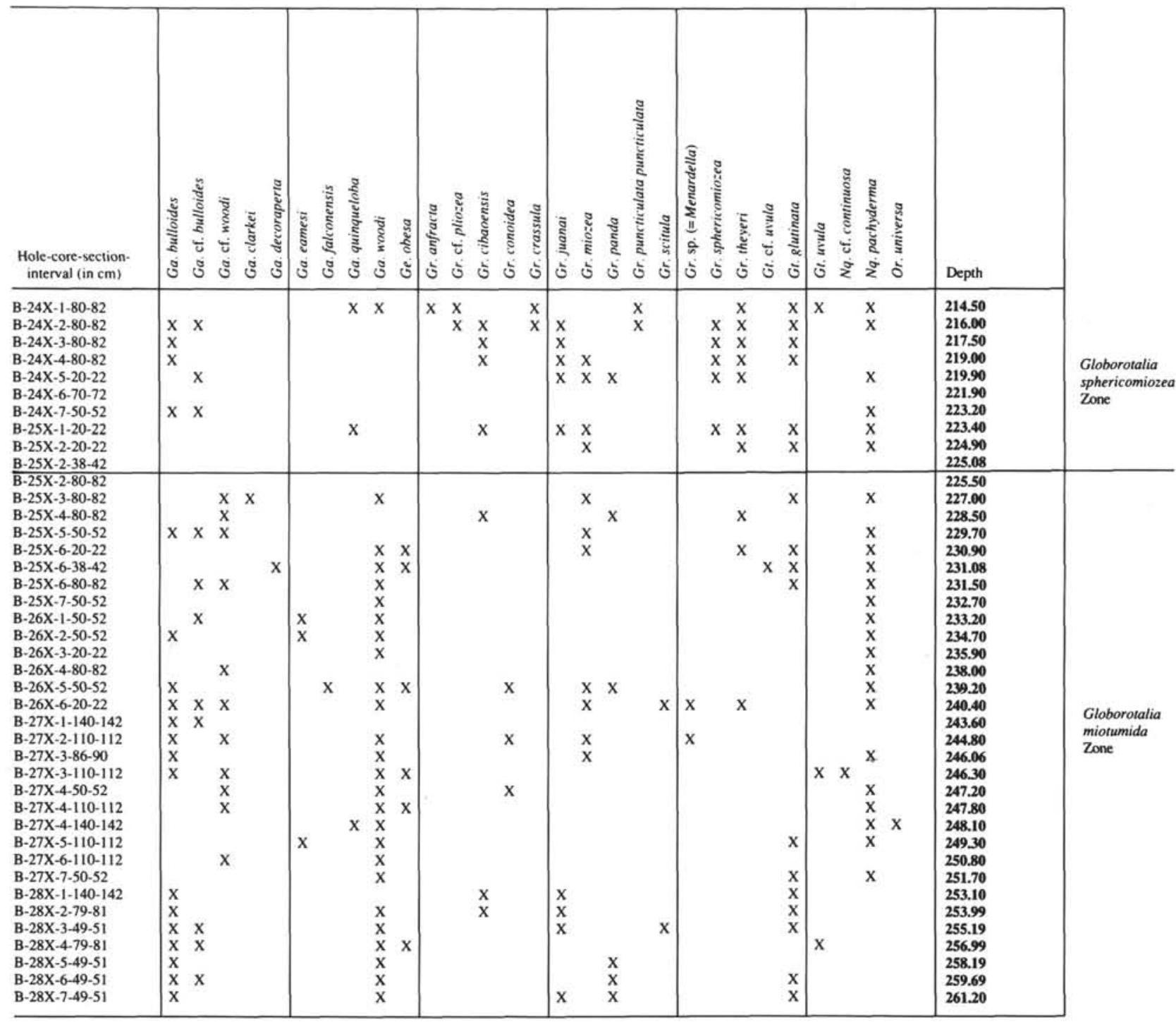

Note: $\mathrm{X}=$ present

Note: Presence/absence by highest appearance. 
Table 5. First and last appearances in the subantarctic Atlantic.

\begin{tabular}{|c|c|c|c|}
\hline Species & Appearance $^{\mathrm{a}}$ & $\begin{array}{l}\mathrm{Age}^{\mathrm{b}} \\
(\mathrm{Ma})\end{array}$ & $\begin{array}{l}\text { Depth } \\
\text { (mbsf) }\end{array}$ \\
\hline \multicolumn{4}{|l|}{ Hole $704 \mathrm{~A}$} \\
\hline Globorotalia truncatulinoides & FA & 0.393 & 7.86 \\
\hline Globorotalia puncticulata puncticuloides & LA & 0.628 & 16.86 \\
\hline Globigerina cariacoensis & LA & 0.667 & 23.68 \\
\hline Globorotalia puncticulata puncticulata & LA & 0.728 & 34.10 \\
\hline Globorotalia cf. pliozea & LA & 1.098 & 51.90 \\
\hline Globorotalia inflata & FA & 2.308 & 150.42 \\
\hline Globorotalia cibaoensis & LA & 2.763 & 173.92 \\
\hline Globigerina woodi & LA & 2.848 & 175.42 \\
\hline Globorotalia juanai & LA & 3.538 & 189.30 \\
\hline Globorotalia cf. margaritae & LA & 3.538 & 189.30 \\
\hline Globigerina cariacoensis & FA & 3.617 & 190.80 \\
\hline Globorotalia puncticulata puncticuloides & FA & 3.696 & 192.30 \\
\hline Globorotalia $\mathrm{cf}$. margaritae & FA & 3.907 & 197.61 \\
\hline Globorotalia crassaformis & FA & 3.929 & 199.11 \\
\hline Globigerinella calida & FA & 3.929 & 199.11 \\
\hline Globorotalia sphericomiozea & LA & 4.307 & 211.00 \\
\hline Globorotalia puncticulata puncticulata & FA & 4.307 & 211.00 \\
\hline Globorotalia cf. pliozea & FA & 4.729 & 219.00 \\
\hline \multicolumn{4}{|l|}{ Hole 704B } \\
\hline Globorotalia miozea & LA & 4.748 & 219.00 \\
\hline Globorotalia sphericomiozea & FA & 5.215 & 223.40 \\
\hline Globorotalia conoidea & LA & 5.826 & 239.20 \\
\hline
\end{tabular}

Note: Reassignment of datums to the more precise depths of the 1990 age model (P. F. Ciesielski, pers. comm.) results in only slight differences in the ages of the first and last appearances at Site 704.

${ }^{\text {a }} \mathrm{FA}=$ first appearance; $\mathrm{LA}=$ last appearance.

b Ages calculated using the 1989 age model.

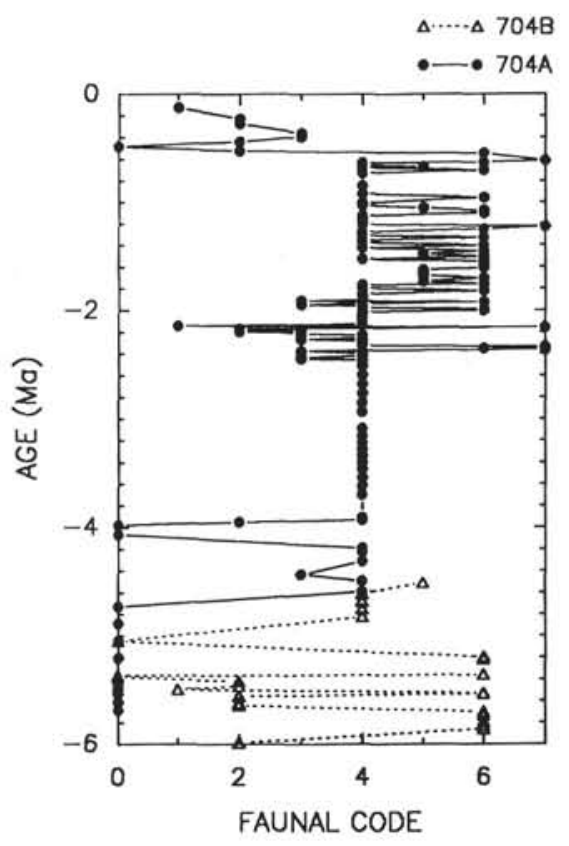

Figure 1. Composite plot of estimate age vs. faunal code for Holes 704A (line with solid circles) and 704B (dashed line with open triangles). Faunal codes are for the dominant genus in each sample: 0 = barren; 1 = Globigerina and Neogloboquadrina $; 2$ = Globigerina ; $3=$ Globigerina and Globorotalia $; 4=$ Globorotalia $; 5=$ Globorotalia and Neogloboquadrina; $6=$ Neogloboquadrina $; 7=$ Globigerina, Globorotalia, and Neogloboquadrina. 
Table 6. Dominant genera in each sample, Holes 704A and 704B.

\begin{tabular}{|c|c|c|c|}
\hline $\begin{array}{l}\text { Core, section, } \\
\text { interval }(\mathrm{cm})\end{array}$ & $\begin{array}{l}\text { Depth } \\
\text { (mbsf) }\end{array}$ & Dominant genera & $\begin{array}{l}\mathrm{Age}^{\mathrm{a}} \\
(\mathrm{Ma})\end{array}$ \\
\hline \multicolumn{4}{|l|}{$114-704 \mathrm{~A}-$} \\
\hline $1 \mathrm{H}-1,70$ & 0.72 & $N q .+G a$. & 0.12 \\
\hline $1 \mathrm{H}-2,70$ & 2.22 & Ga. & 0.23 \\
\hline $1 \mathrm{H}-3,70$ & 3.72 & Ga. & 0.27 \\
\hline $1 \mathrm{H}-5,70$ & 6.72 & Ga. + Gr. & 0.36 \\
\hline $2 \mathrm{H}-1,64$ & 7.86 & Ga. + Gr. & 0.39 \\
\hline $2 \mathrm{H}-2,64$ & 9.36 & Ga. & 0.44 \\
\hline $2 \mathrm{H}-3,64$ & 10.86 & Near barren & 0.48 \\
\hline $2 \mathrm{H}-4,64$ & 12.36 & Ga. & 0.53 \\
\hline $2 \mathrm{H}-5,64$ & 13.00 & $N q$. & 0.55 \\
\hline $2 \mathrm{H}-6,64$ & 15.36 & $\mathrm{Nq} .+\mathrm{Ga} .+\mathrm{Gr}$. & 0.61 \\
\hline $2 \mathrm{H}-7,30$ & 16.86 & $N q$. & 0.63 \\
\hline $3 \mathrm{H}-1,96$ & 17.68 & $G r$. & 0.63 \\
\hline $3 \mathrm{H}-2,96$ & 19.18 & $G r$. & 0.64 \\
\hline $3 \mathrm{H}-3,96$ & 20.68 & $G r$. & 0.65 \\
\hline $3 \mathrm{H}-4,96$ & 22.18 & Gr. & 0.66 \\
\hline $3 \mathrm{H}-5,96$ & 23.68 & $\mathrm{Nq} .+\mathrm{Ga} .+\mathrm{Gr}$. & 0.67 \\
\hline $3 \mathrm{H}-6,96$ & 25.18 & Gr. & 0.68 \\
\hline $4 \mathrm{H}-3,68$ & 29.90 & $\mathrm{Nq}$. & 0.70 \\
\hline $4 \mathrm{H}-6,38$ & 34.10 & Gr. & 0.73 \\
\hline $5 \mathrm{H}-3,29$ & 39.01 & Gr. & 0.84 \\
\hline $5 \mathrm{H}-5,29$ & 42.01 & Gr. & 0.92 \\
\hline $5 \mathrm{H}-6,29$ & 43.51 & $N q$. & 0.96 \\
\hline $6 \mathrm{H}-1,68$ & 45.90 & Gr. & 1.00 \\
\hline $6 \mathrm{H}-2,68$ & 47.40 & Gr. & 1.03 \\
\hline $6 \mathrm{H}-3,68$ & 48.90 & $N q .+G r$. & 1.05 \\
\hline $6 \mathrm{H}-4,68$ & 50.40 & $N q$ & 1.07 \\
\hline $6 \mathrm{H}-5,68$ & 51.90 & $N q$. & 1.10 \\
\hline $6 \mathrm{H}-6,68$ & 53.40 & Gr. & 1.12 \\
\hline $6 \mathrm{H}-7,28$ & 54.50 & Gr. & 1.14 \\
\hline $7 \mathrm{H}-2,70$ & 56.92 & Gr. & 1.18 \\
\hline $7 \mathrm{H}-3,68$ & 58.40 & Gr. & 1.20 \\
\hline $7 \mathrm{H}-4,71$ & 59.93 & $\mathrm{Nq} .+\mathrm{Ga} .+\mathrm{Gr}$. & 1.23 \\
\hline $7 \mathrm{H}-5,70$ & 61.42 & $N q$ & 1.25 \\
\hline $7 \mathrm{H}-6,73$ & 62.95 & Gr. & 1.27 \\
\hline $8 \mathrm{H}-1,69$ & 64.91 & Gr. & 1.30 \\
\hline $8 \mathrm{H}-2,69$ & 66.41 & $N q$. & 1.33 \\
\hline $8 \mathrm{H}-3,69$ & 67.91 & Gr. & 1.35 \\
\hline $8 \mathrm{H}-4,69$ & 69.41 & $G r$. & 1.38 \\
\hline $8 \mathrm{H}-5,69$ & 70.91 & $N q$. & 1.40 \\
\hline $8 \mathrm{H}-6,69$ & 72.41 & Gr. & 1.42 \\
\hline $9 \mathrm{H}-1,68$ & 74.41 & $N q$. & 1.45 \\
\hline $9 \mathrm{H}-2,68$ & 75.91 & $N q .+G r$. & 1.48 \\
\hline $9 \mathrm{H}-3,68$ & 77.41 & $N q$ & 1.50 \\
\hline $9 \mathrm{H}-4,68$ & 78.91 & Gr. & 1.53 \\
\hline $9 \mathrm{H}-5,68$ & 80.41 & $\mathrm{Ng}$. & 1.55 \\
\hline $9 \mathrm{H}-6,68$ & 81.91 & $\mathrm{Ng}$. & 1.57 \\
\hline $9 \mathrm{H}-7,8$ & 82.81 & $N q$. & 1.59 \\
\hline $10 \mathrm{H}-1,68$ & 83.90 & $N q$. & 1.61 \\
\hline $10 \mathrm{H}-2,68$ & 85.40 & $\mathrm{Nq} .+\mathrm{Gr}$. & 1.63 \\
\hline $10 \mathrm{H}-3,68$ & 86.90 & $\mathrm{Nq} .+\mathrm{Gr}$. & 1.65 \\
\hline $10 \mathrm{H}-4,68$ & 88.40 & $\mathrm{Nq} .+\mathrm{Gr}$. & 1.68 \\
\hline $10 \mathrm{H}-5,68$ & 89.90 & Gr. & 1.71 \\
\hline $10 \mathrm{H}-6,68$ & 91.40 & $\mathrm{Nq} .+\mathrm{Gr}$. & 1.73 \\
\hline $10 \mathrm{H}-7,68$ & 92.90 & $N q$ & 1.76 \\
\hline $11 \mathrm{H}-1,70$ & 93.42 & Gr. & 1.77 \\
\hline $11 \mathrm{H}-2,70$ & 94.92 & Gr. & 1.80 \\
\hline $11 \mathrm{H}-3,70$ & 96.42 & $N q$. & 1.82 \\
\hline $11 \mathrm{H}-4,70$ & 97.92 & Gr. & 1.85 \\
\hline $11 \mathrm{H}-5,63$ & 99.35 & $G r$. & 1.87 \\
\hline $11 \mathrm{H}-6,70$ & 100.92 & Gr. & 1.90 \\
\hline $11 \mathrm{H}-7,10$ & 101.82 & Gr. & 1.90 \\
\hline $12 \mathrm{H}-1,70$ & 102.92 & $G a .+G r$. & 1.91 \\
\hline $12 \mathrm{H}-2,70$ & 104.42 & $N q$. & 1.92 \\
\hline $12 \mathrm{H}-3,70$ & 105.92 & $G r$. & 1.94 \\
\hline $12 \mathrm{H}-4,70$ & 107.42 & $G a .+G r$. & 1.95 \\
\hline $12 \mathrm{H}-5,70$ & 108.92 & Gr. & 1.96 \\
\hline $12 \mathrm{H}-6,70$ & 110.42 & $G r$. & 1.97 \\
\hline $13 \mathrm{H}-1,70$ & 112.42 & $N q$. & 1.99 \\
\hline $13 \mathrm{H}-2,70$ & 113.92 & $N q$. & 2.00 \\
\hline $13 \mathrm{H}-3,72$ & 115.44 & Gr. & 2.01 \\
\hline $13 \mathrm{H}-4,70$ & 116.92 & Gr. & 2.02 \\
\hline $13 \mathrm{H}-5,70$ & 118.42 & $G r$. & 2.04 \\
\hline $13 \mathrm{H}-6,70$ & 119.92 & $G r$. & 2.05 \\
\hline $13 \mathrm{H}-7,10$ & 120.82 & Gr. & 2.06 \\
\hline $14 \mathrm{H}-1,70$ & 121.92 & $G r$. & 2.06 \\
\hline
\end{tabular}

Table 6 (continued).

\begin{tabular}{|c|c|c|c|}
\hline $\begin{array}{l}\text { Core, section, } \\
\text { interval }(\mathrm{cm})\end{array}$ & $\begin{array}{l}\text { Depth } \\
\text { (mbsf) }\end{array}$ & Dominant genera & $\begin{array}{l}\mathrm{Age}^{\mathrm{a}} \\
(\mathrm{Ma})\end{array}$ \\
\hline $14 \mathrm{H}-2,70$ & 123.42 & Gr. & 2.08 \\
\hline $14 \mathrm{H}-3,70$ & 124.92 & Gr. & 2.09 \\
\hline $14 \mathrm{H}-4,70$ & 126.42 & Gr. & 2.10 \\
\hline $14 \mathrm{H}-5,70$ & 127.92 & Gr. & 2.11 \\
\hline $14 \mathrm{H}-6,70$ & 129.42 & Gr. & 2.12 \\
\hline $15 \mathrm{H}-1,70$ & 131.42 & $N q .+\mathrm{Ga}$. & 2.14 \\
\hline $15 \mathrm{H}-2,70$ & 132.92 & $\mathrm{Nq} .+\mathrm{Ga} .+\mathrm{Gr}$ & 2.15 \\
\hline $15 \mathrm{H}-3,70$ & 134.42 & Ga. & 2.17 \\
\hline $15 \mathrm{H}-4,70$ & 135.92 & $G a .+G r$. & 2.18 \\
\hline $15 \mathrm{H}-5,70$ & 137.42 & Ga. & 2.19 \\
\hline $15 \mathrm{H}-6,70$ & 138.92 & $G a .+G r$. & 2.21 \\
\hline $15 \mathrm{H}-7,70$ & 139.82 & Ga. + Gr. & 2.21 \\
\hline $16 \mathrm{H}-1,70$ & 140.92 & Gr. & 2.22 \\
\hline $16 \mathrm{H}-2,70$ & 142.42 & Gr. & 2.24 \\
\hline $16 \mathrm{H}-3,70$ & 143.92 & Gr. & 2.25 \\
\hline $16 \mathrm{H}-4,70$ & 145.42 & Ga. + Gr. & 2.26 \\
\hline $16 \mathrm{H}-5,70$ & 146.92 & Gr. & 2.28 \\
\hline $16 \mathrm{H}-6,70$ & 148.42 & Gr. & 2.29 \\
\hline $17 \mathrm{X}-1,70$ & 150.42 & Gr. & 2.31 \\
\hline $17 X-2,70$ & 151.92 & Gr. & 2.32 \\
\hline $17 X-3,70$ & 153.42 & $\mathrm{Nq} .+\mathrm{Ga} .+\mathrm{Gr}$. & 2.33 \\
\hline $17 X-4,70$ & 154.92 & $N q$. & 2.35 \\
\hline $17 X-5,70$ & 156.42 & $N q .+G a .+G r$. & 2.36 \\
\hline $17 X-6,70$ & 157.92 & $G a .+G r$ & 2.37 \\
\hline $18 X-1,70$ & 159.92 & Gr. & 2.39 \\
\hline $18 X-2,70$ & 161.42 & Gr. & 2.41 \\
\hline $18 X-3,70$ & 162.92 & Gr. & 2.42 \\
\hline $18 X-4,70$ & 164.42 & $G a .+G r$ & 2.43 \\
\hline $18 X-5,70$ & 165.92 & Ga. + Gr. & 2.45 \\
\hline $18 X-6,70$ & 167.42 & Gr. & 2.46 \\
\hline $19 X-1,70$ & 169.42 & Gr. & 2.51 \\
\hline $19 X-2,70$ & 170.92 & Gr. & 2.59 \\
\hline $19 X-3,70$ & 172.42 & Gr. & 2.68 \\
\hline $19 X-4,70$ & 173.92 & Gr. & 2.76 \\
\hline $19 X-5,70$ & 175.42 & Gr. & 2.85 \\
\hline $19 X-6,70$ & 176.92 & Gr. & 2.93 \\
\hline $20 X-1,90$ & 179.12 & Gr. & 3.09 \\
\hline $20 \mathrm{X}-2,90$ & 180.62 & Gr. & 3.16 \\
\hline $20 \mathrm{X}-3,90$ & 182.12 & Gr. & 3.22 \\
\hline $20 \mathrm{X}-4,90$ & 183.62 & Gr. & 3.28 \\
\hline $20 X-5,90$ & 185.12 & Gr. & 3.34 \\
\hline $20 \mathrm{X}-6,90$ & 186.62 & $G r$. & 3.40 \\
\hline $21 X-1,8$ & 187.80 & Gr. & 3.46 \\
\hline $21 X-2,8$ & 189.30 & Gr. & 3.54 \\
\hline $21 X-3,8$ & 190.80 & Gr. & 3.62 \\
\hline $21 X-4,8$ & 192.30 & Gr. & 3.70 \\
\hline $22 \times-1,39$ & 197.61 & Gr. & 3.91 \\
\hline $22 \times-2,39$ & 199.11 & Gr. & 3.93 \\
\hline $22 X-3,39$ & 200.61 & Ga. & 3.95 \\
\hline $22 X-4,39$ & 202.11 & Near barren & 3.98 \\
\hline $22 X-5,39$ & 203.61 & Near barren & 4.07 \\
\hline $23 \mathrm{X}-1,128$ & 208.00 & Gr. & 4.19 \\
\hline $23 \mathrm{X}-2,128$ & 209.50 & Gr. & 4.22 \\
\hline $23 \mathrm{X}-3,128$ & 211.00 & Gr. & 4.31 \\
\hline $23 \mathrm{X}-4,128$ & 212.50 & $G a .+G r$. & 4.43 \\
\hline $23 \mathrm{X}-5,128$ & 214.00 & Gr. & 4.49 \\
\hline $24 \mathrm{X}-1,128$ & 217.50 & Gr. & 4.59 \\
\hline $24 \mathrm{X}-2,128$ & 219.00 & Near barren & 4.73 \\
\hline $24 X-3,128$ & 220.50 & Near barren & 4.88 \\
\hline $24 \mathrm{X}-4,128$ & 222.00 & Near barren & 5.04 \\
\hline $24 X-5,128$ & 223.50 & Near barren & 5.20 \\
\hline $25 \mathrm{X}-1,100$ & 226.72 & Near barren & 5.40 \\
\hline $25 X-2,100$ & 228.22 & Near barren & 5.45 \\
\hline $25 \mathrm{X}-3,100$ & 229.72 & Near barren & 5.49 \\
\hline $25 \mathrm{X}-4,100$ & 231.22 & Near barren & 5.54 \\
\hline $25 X-5,100$ & 232.72 & Near barren & 5.62 \\
\hline $25 X-6,100$ & 234.22 & Near barren & 5.69 \\
\hline \multicolumn{4}{|l|}{$114-704 \mathrm{~B}-$} \\
\hline $24 \mathrm{X}-1,80$ & 214.50 & $G r .+N q$. & 4.51 \\
\hline $24 \mathrm{X}-2,80$ & 216.00 & Gr. & 4.60 \\
\hline $24 X-3,80$ & 217.50 & Gr. & 4.68 \\
\hline $24 \mathrm{X}-4,80$ & 219.00 & Gr. & 4.75 \\
\hline $24 X-5,20$ & 219.90 & Gr. & 4.82 \\
\hline $24 X-6,70$ & 221.90 & Barren & 5.05 \\
\hline $24 X-7,50$ & 223.20 & $N q$. & 5.19 \\
\hline $25 \mathrm{X}-1,20$ & 223.40 & $\mathrm{Nq}$. & 5.22 \\
\hline $25 \mathrm{X}-2,20$ & 224.90 & $N q$. & 5.36 \\
\hline
\end{tabular}


Table 6 (continued).

\begin{tabular}{|c|c|c|c|}
\hline $\begin{array}{l}\text { Core, section, } \\
\text { interval }(\mathrm{cm})\end{array}$ & $\begin{array}{l}\text { Depth } \\
\text { (mbsf) }\end{array}$ & Dominant genera & $\begin{array}{l}\mathrm{Age}^{\mathrm{a}} \\
(\mathrm{Ma})\end{array}$ \\
\hline $25 \mathrm{X}-2,38$ & 225.08 & Barren & 5.36 \\
\hline $25 X-2,80$ & 225.50 & Barren & 5.38 \\
\hline $25 \mathrm{X}-3,80$ & 227.00 & Ga. & 5.42 \\
\hline $25 X-4,80$ & 228.50 & Ga. & 5.46 \\
\hline $25 X-5,50$ & 229.70 & $G a .+N q$. & 5.49 \\
\hline $25 X-6,20$ & 230.90 & $\mathrm{Nq}$. & 5.53 \\
\hline $25 X-6,38$ & 231.08 & $N q$. & 5.53 \\
\hline $25 X-6,80$ & 231.50 & Ga. & 5.56 \\
\hline $25 X-7,50$ & 232.70 & Ga. & 5.62 \\
\hline $26 \mathrm{X}-1,50$ & 233.20 & Ga. & 5.64 \\
\hline $26 \mathrm{X}-2,50$ & 234.70 & $N q$. & 5.70 \\
\hline $26 \mathrm{X}-3,20$ & 235.90 & $\mathrm{Nq}$. & 5.73 \\
\hline $26 X-4,80$ & 238.00 & $N q$. & 5.79 \\
\hline $26 X-5,50$ & 239.20 & $N q$. & 5.83 \\
\hline $26 X-6,20$ & 240.40 & $N q$. & 5.86 \\
\hline $27 X-1,140$ & 243.60 & Ga. & 5.98 \\
\hline $27 X-2,110$ & 244.80 & Ga. & 6.04 \\
\hline $27 X-3,86$ & 246.06 & Ga. & 6.10 \\
\hline $27 X-3,110$ & 246.30 & Ga. & 6.11 \\
\hline $27 X-4,50$ & 247.20 & Ga. & 6.15 \\
\hline $27 X-4,110$ & 247.80 & Ga. & 6.17 \\
\hline $27 X-4,140$ & 248.10 & Ga. & 6.19 \\
\hline $27 X-5,110$ & 249.30 & Ga. & 6.24 \\
\hline $27 X-6,110$ & 250.80 & Ga. & 6.31 \\
\hline $27 X-7,50$ & 251.70 & Ga. & 6.35 \\
\hline $28 X-1,140$ & 253.10 & $N q$. & 6.39 \\
\hline $28 X-2,79$ & 253.99 & $\mathrm{Nq}$. & 6.41 \\
\hline $28 \mathrm{X}-3,49$ & 255.19 & Ga. & 6.44 \\
\hline $28 X-4,79$ & 256.99 & Ga. & 6.49 \\
\hline $28 X-5,49$ & 258.19 & $N q .+\mathrm{Ga}$. & 6.57 \\
\hline $28 X-6,49$ & 259.69 & Ga. & 6.70 \\
\hline $28 X-7,49$ & 261.20 & Ga. & 6.73 \\
\hline
\end{tabular}

a The revised 1990 age model (P. F. Ciesielski, pers. comm.) results in only slight age differences (see Table 1). 


\section{A. BRUNNER}

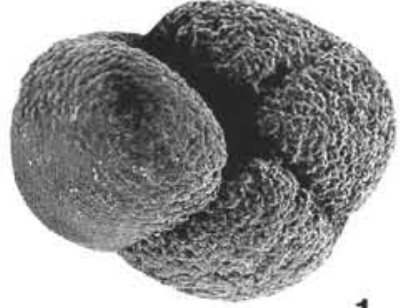

1

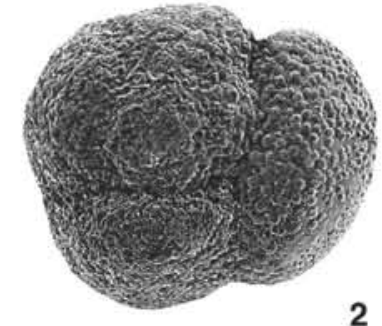

2
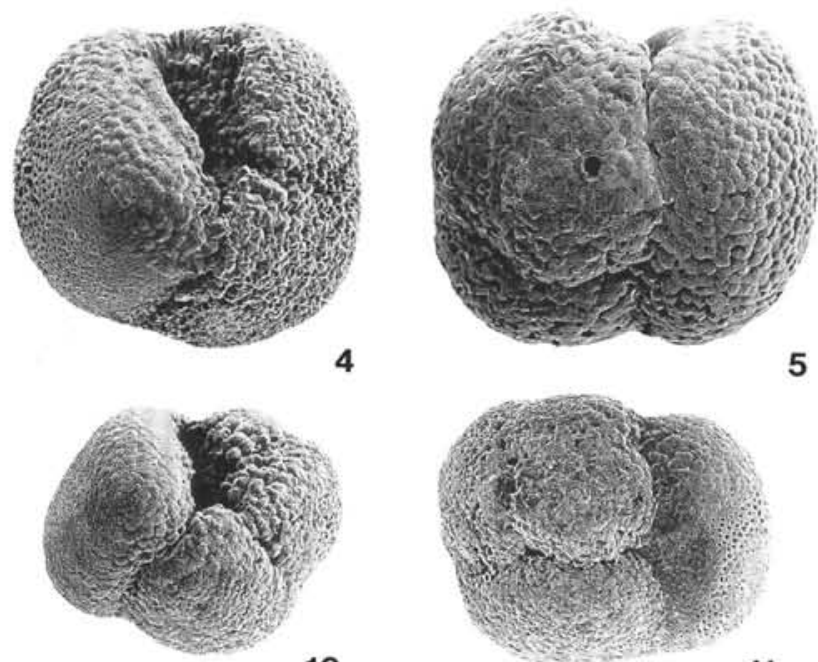

10

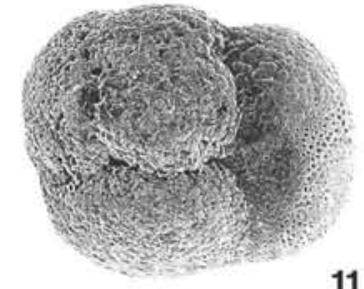

11

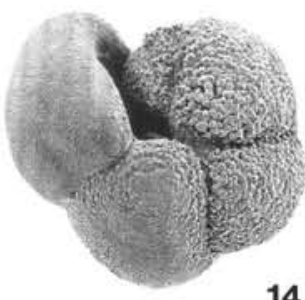

14
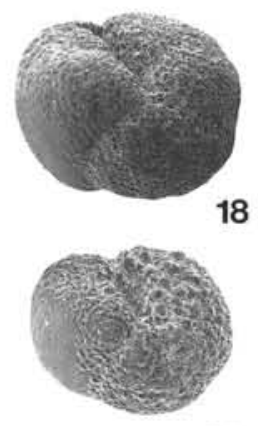

21
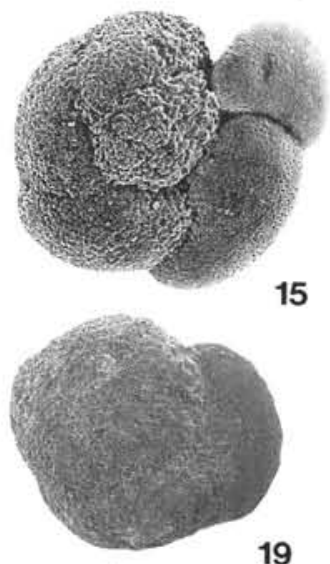

19

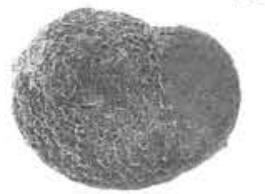

22

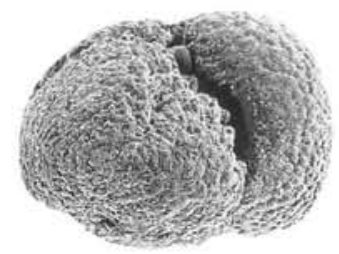

3

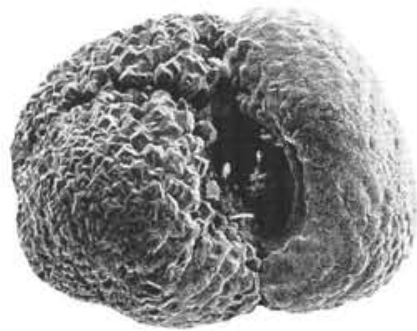

6

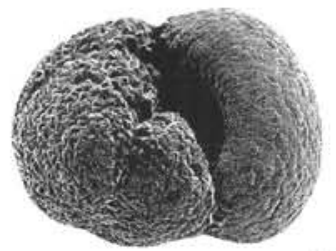

12
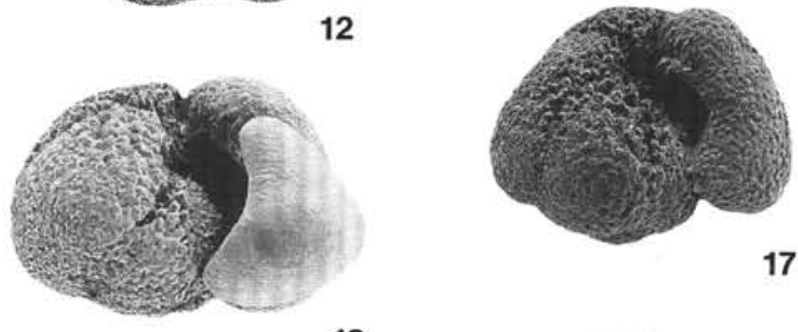

17

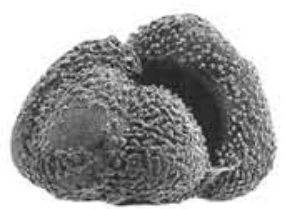

9

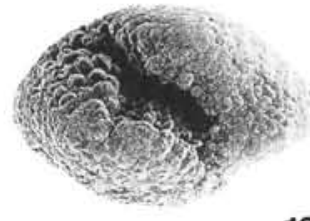

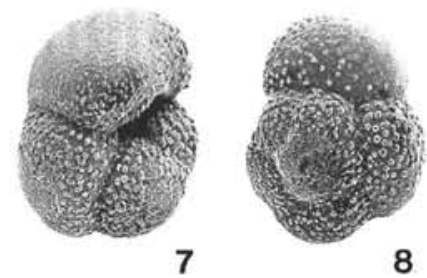

13

16

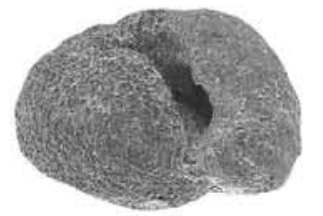

20

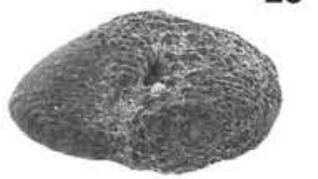

23

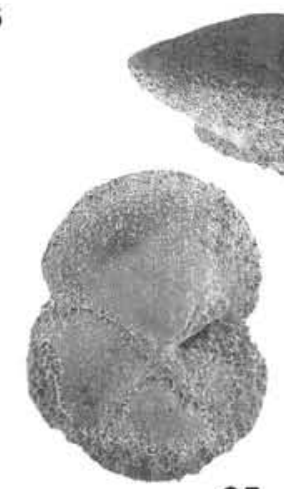

25

Plate 1. 1. Globorotalia crassaformis, umbilical view, $\times 125$, Sample 114-704A-19X-4, $70-74 \mathrm{~cm}$. 2. Globorotalia crassaformis, spiral view, $\times 125$, Sample 114-704A-19X-3, 70-74 cm. 3. Globorotalia crassaformis, side view, $\times 125$, Sample 114-704A-19X-4, 70-74 cm. 4. Globorotalia inflata, umbilical view, $\times 125$, Sample 114-704A-15H-5, 70-74 cm. 5. Globorotalia inflata, spiral view, $\times 150$, Sample 114-704A-15H-5, 70-74 cm. 6. Globorotalia inflata, side view, $\times 125$, Sample 114-704A-15H-5, 70-74 cm. 7. Globorotalia puncticulata var. A, umbilical view, $\times 100$, Sample 114-704A-15H-3, 70-74 cm. 8. Globorotalia puncticulata var. A, spiral view, $\times 100$, Sample 114-704A-15H-4, 70-74 cm. 9. Globorotalia puncticulata var. A, side view, $\times 100$, Sample 114-704A-15H-4, 70-74 cm. 10. Globorotalia puncticulata puncticulata, umbilical view, $\times 100$, Sample $114-704$ A$15 \mathrm{H}-3,70-74 \mathrm{~cm}$. 11. Globorotalia puncticulata puncticulata, spiral view, $\times 100$, Sample $114-704 \mathrm{~A}-14 \mathrm{H}-5,70-74 \mathrm{~cm}$. 12. Globorotalia puncticulata puncticulata, side view, $\times 100$, Sample 114-704A-15H-4, 70-74 cm. 13. Globorotalia $\mathrm{cf}$. pliozea, side view, $\times 125$, Sample 114-704A-18X-5, 70-74 cm. 14. Globorotalia puncticulata puncticuloides, umbilical view, $\times 85$, Sample $114-704 \mathrm{~A}-3 \mathrm{H}-1,96-100 \mathrm{~cm}$. 15. Globorotalia puncticulata puncticuloides, spiral view, $\times 85$, Sample 114-704A-3H-1, 96-100 cm. 16. Globorotalia puncticulata puncticuloides, side view, $\times 85$, Sample 114-704A-3H-1, 96-100 $\mathrm{cm}$. 17. Globorotalia cf. sphericomiozea, side view, $\times 125$, Sample 114-704A-24X-1, 128-132 cm. 18. Globorotalia sphericomiozea, umbilical view, $\times 150$, Sample 114-704B-24X-2, 80-82 cm. 19. Globorotalia sphericomiozea, spiral view, $\times 150$, Sample 114-704B-24X-2, 80-82 cm. 20. Globorotalia sphericomiozea, side view, $\times 150$, Sample 114-704B-24X-1, 80-82 cm. 21. Globorotalia miozea, umbilical view, $\times 200$, Sample 114-704B-26X-6, 20-22 $\mathrm{cm}$. 22. Globorotalia miozea, spiral view, $\times 200$, Sample 114-704B-26X-6, 20-22 cm. 23. Globorotalia miozea, side view, $\times 200$, Sample 114-704B-26X-5, 50-52 cm. 24. Globorotalia panda, side view, $\times 200$, Sample 114-704B-28X-5, 49-51 cm. 25. Globorotalia panda, umbilical view, $\times 200$, Sample 114-704B-28X-5, 49-51 cm. 26. Globorotalia panda, spiral view, $\times 200$, Sample 114-704B-28X-5, 49-51 cm. 


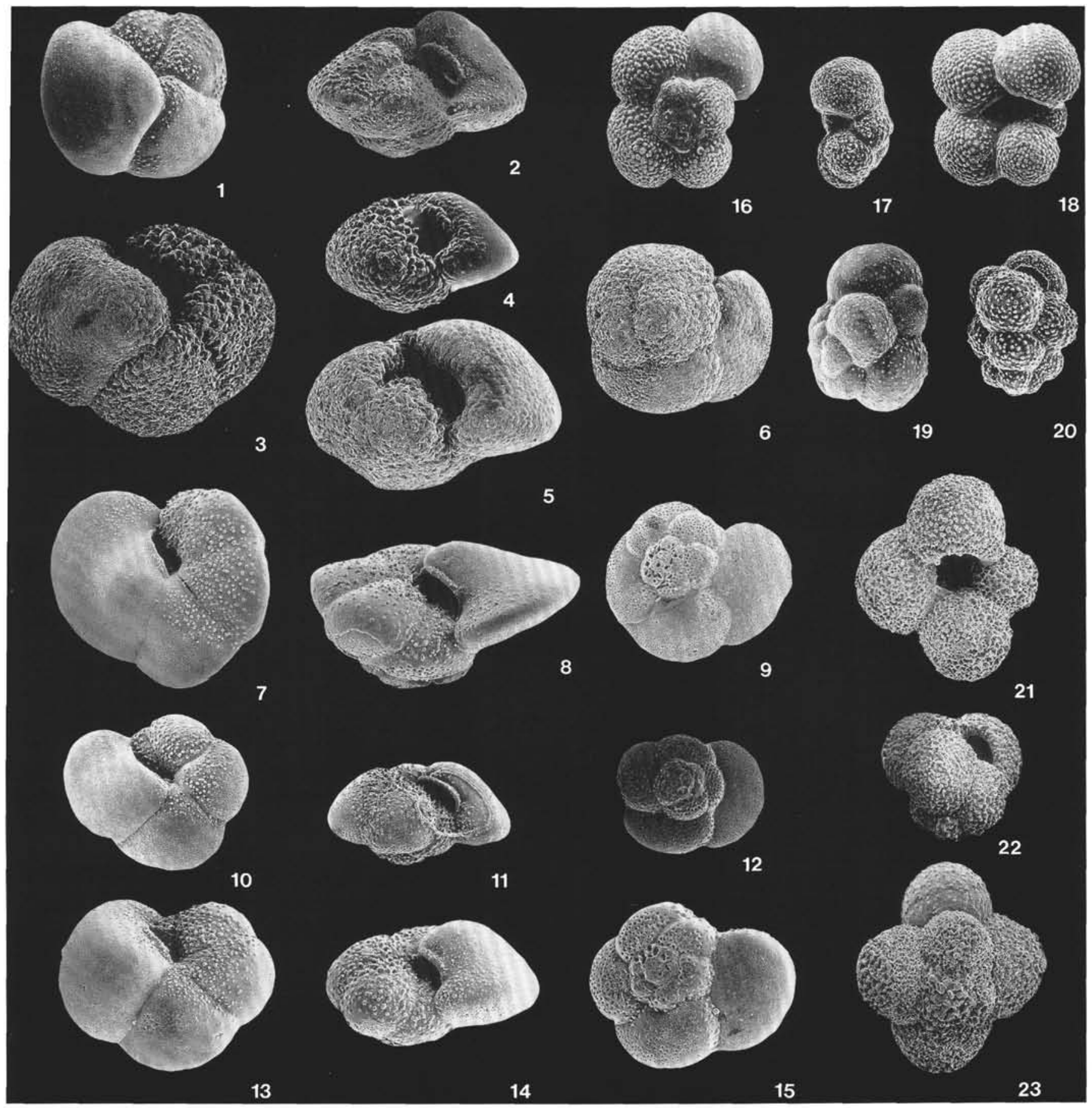

Plate 2. 1. Globorotalia crassula, umbilical view, $\times 150$, Sample $114-704$ A-2H-1, 64-68 cm. 2. Globorotalia crassula, side view, $\times 150$, Sample 114-704A-2H-1, 64-68 cm. 3. Globorotalia cf. pliozea, umbilical view, $\times 100$, Sample 114-704A-18X-5, 70-74 cm. 4. Globorotalia cf. pliozea, side view, $\times 125$, Sample 114-704A-8H-4, 69-73 cm. 5. Globorotalia cf. pliozea, side view, $\times 100$, Sample 114-704A-18X-5, 70-74 cm. 6. Globorotalia cf. pliozea, spiral view, $\times 100$, Sample 114-704A-18X-5, 70-74 cm. 7. Globorotalia $\mathrm{cf}$ margaritae, umbilical view, $\times 100$, Sample 114-704A$21 \mathrm{X}-2,8-12 \mathrm{~cm}$. 8. Globorotalia $\mathrm{cf}$. margaritae, side view, $\times 175$, Sample 114-704A-21X-2, 8-12 cm. 9. Globorotalia cf. margaritae, spiral view, $\times 100$, Sample 114-704A-21X-2, 8-12 cm. 10. Globorotalia cibaoensis, umbilical view, $\times 125$, Sample 114-704A-24X-1, $128-132 \mathrm{~cm} .11$. Globorotalia cibaoensis, side view, $\times 125$, Sample $114-704 \mathrm{~A}-24 \mathrm{X}-1,128-132 \mathrm{~cm}$. 12. Globorotalia cibaoensis, spiral view, $\times 125$, Sample 114-704A-24X-1, 128-132 cm. 13. Globorotalia juanai, umbilical view, $\times 175$, Sample 114-704A-21X-2, 8-12 cm. 14. Globorotalia juanai, side view, $\times 175$, Sample 114-704A-21X-3, 8-12 cm. 15. Globorotalia juanai, spiral view, $\times 175$, Sample 114-704A-21X-2, 8-12 cm. 16. Globigerinella calida, umbilical view, $\times 200$, Sample 114-704A-9H-4, 68-72 cm. 17. Globigerinella calida, side view, $\times 200$, Sample 114-704A-9H-4, 68-72 cm. 18. Globigerinella calida, spiral view, $\times 200$, Sample $114-704 \mathrm{~A}-9 \mathrm{H}-4,68-72 \mathrm{~cm} .19$. Globigerinita $\mathrm{cf}$. uvula, side view, $\times 450$, Sample 114-704A-8H-1, 69-73 cm. A bulla covers the aperture at the center, right margin of the specimen. 20. Globigerinita uvula, side view, $\times 400$, Sample 114-704A-7H-4, 71-75 cm. 21. Globigerina cariacoensis, umbilical view, $\times 100$, Sample 114-704A-12H-5, 70-74 cm. 22. Globigerina cariacoensis, side view, $\times 100$, Sample 114-704A-14H-4, 70-74 cm. 23. Globigerina cariacoensis, spiral view, $\times 100$, Sample 114-704A-12H-4, $70-74 \mathrm{~cm}$. 